CEB Policy Paper

\title{
The Vietnamese financial economy: reforms and development, 1986-2016
}

\section{Quan Hoang Vuong}

In an age of reform, Vietnam's financial systems have come to a critical stage in which the quality of policy-making, independence of the central banking operations and over-risk controls will ultimately be required if the country is set to move forward in a sustainable fashion. Analysts may have different views about Vietnam's financial economy, but all agree that it has evolved and grown fast over the past three decades. The next course of development will depend on how Vietnamese society views raison d'être of its financial systems and financial health. But the process will much depend on the economic growth of the economy as a whole. Failing to support a sustained growth puts VFS's existence at risk as economic growth helps mitigate higher risk-taking behavior and contain instability in less competitive markets.

Keywords: Financial economy, reforms, emerging market, money market, capital market

JEL Classifications: E44, E58, F36, G00 


\title{
The Vietnamese financial economy: reforms and development, 1986-2016
}

\author{
Quan Hoang Vuong \\ Université Libre de Bruxelles \\ Email: qvuong@ulb.ac.be or qvuong.ulb@gmail.com
}

\begin{abstract}
:
In an age of reform, Vietnam's financial systems have come to a critical stage in which the quality of policy-making, independence of the central banking operations and over-risk controls will ultimately be required if the country is set to move forward in a sustainable fashion. Analysts may have different views about Vietnam's financial economy, but all agree that it has evolved and grown fast over the past three decades. The next course of development will depend on how Vietnamese society views raison d'être of its financial systems and financial health. But the process will much depend on the economic growth of the economy as a whole. Failing to support a sustained growth puts VFS's existence at risk as economic growth helps mitigate higher risk-taking behavior and contain instability in less competitive markets.
\end{abstract}

Keywords: Financial economy, reforms, emerging market, money market, capital market

JEL Codes: E44, E58, F36, G00

\section{Note for readers:}

Draft version: v22; April 30, 2017

Revised: November 30, 2018

A major part of this paper has been published in Routledge Handbook of Banking and Finance in Asia. If you use the information provided in this paper, please cite:

Vuong, Q.H. (2019). "The financial economy of Viet Nam in an age of reform, 1986-2016". In U. Volz, P. Morgan and N. Yoshino (Eds.) Routledge Handbook of Banking and Finance in Asia (pp. 201-222). New York, NY: Routledge. 


\section{Introduction}

Before the launch of extensive economic reforms, usually referred to as Doi Moi, Vietnam's economy was devastated by 30 -year warfares with two world's military powers, France and the United States, ending in 1975. In the next 10 years Vietnam suffered from major failing economic experiments from 'cooperatization' in agriculture, "industry and commerce rehabilitation", price-wage-currency reform, etc. under the centrally planned mechanism (Wood 1989), as well as the international isolation and U.S. trade embargo when its troops entered Cambodia to overthrow Khmer Rouge (Riedel \& Turley 1999). Worse off, a brief border war with China in 1979 led to suspended economic activities and a shortage of production materials in many years. Vietnam's gross domestic product (GDP) per capita declined to US\$97 in 1989 whereas External Debt/GDP reached 330\% (Vuong 2010).[1] The economy languished and became one of the poorest in the world.

Things have since changed. With a 92-million population, its GDP was US\$204 billion in 2015, resulting in a GDP per capita of US\$2,282 after 30 years of socioeconomic transitions, a remarkable achievement compared to US\$437 in 1986. Doi Moi has enabled the marketization/internationalization of the economy, bringing about the fruits of the market (Dutta 1995; Napier \& Vuong 2013b; Riedel \& Turley 1999; Vuong 2010), with the financial system facilitating the transformation (Siregar 1997). The banking system had total assets of US $\$ 307$ billion in 2015, approximately 150\% of GDP.

A vibrant business sector is behind the growing financial sector. According to the Ministry of Planning and Investment (MPI), 94,700 enterprises were created in 2015, registering an additional capital of US $\$ 27.3$ billion. Nonetheless, some problems remain in both macro-policy realm and corporate sector's microstructure (Oh 1999; Riedel \& Turley 1999; Pincus 2015) as in 2015, 80,900 enterprises dissolved or temporarily closed, 50\% higher than that of 2011 (Fig. 1). Part of the reasons for business failures rests with the financial sector itself. In short, a well-functioning financial system is a sine qua non for Vietnam's sustained growth (Vuong 2016a).

Figure 1. Newly created vs. closed/stopped businesses

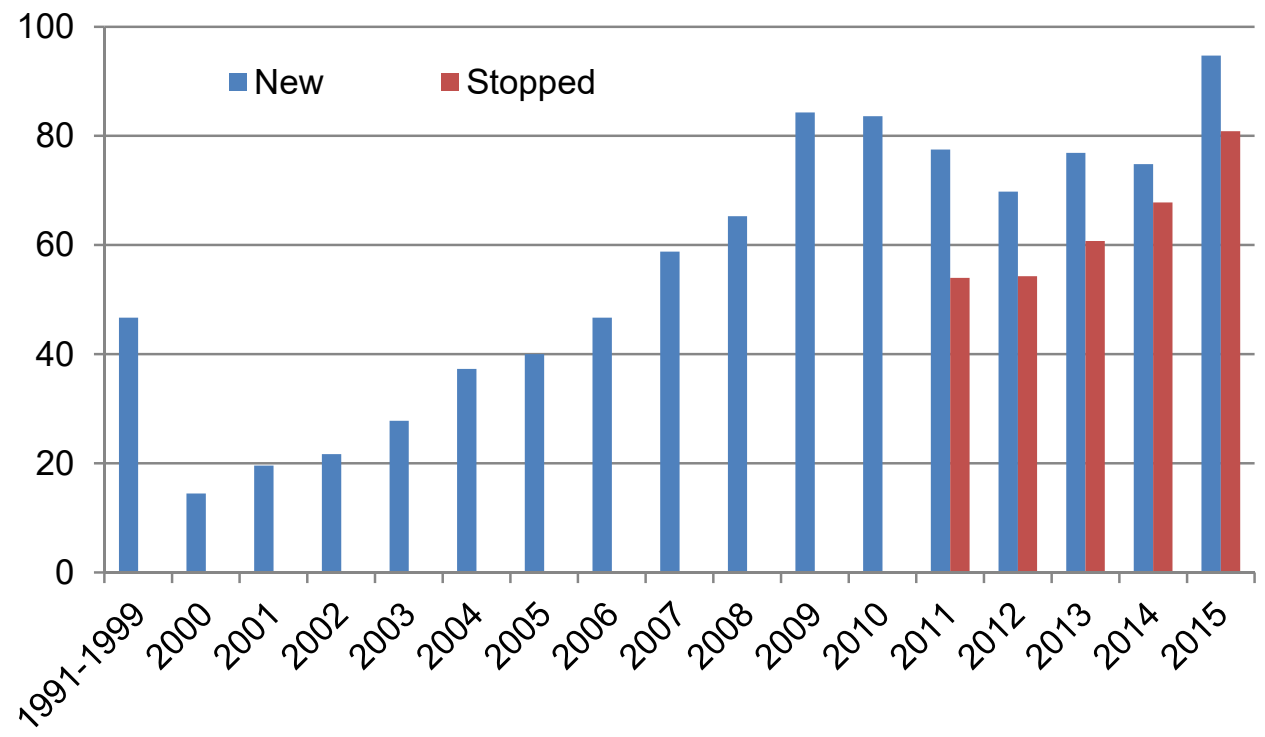

Source: MPI. Unit: 1000/year. 


\section{Economic foundations and governance framework}

\section{Economic foundations}

The restoring of economic stability laid out economic foundations for the development of the financial system, and its thriving forms of institution, growing asset and equity bases (Roman 1995; Oh 1999). Success in fighting 1990s inflation rested with the management of exchange rate fluctuations combined with a restrictive monetary policy that contained broad money (M2) supply (Gourjon 2006). In addition, the surge of economic activities has turned opportunities resulting from Doi Moi into positive GDP changes, for a growing population of Vietnam (Fig. 2).

Figure 2. GDP in current prices

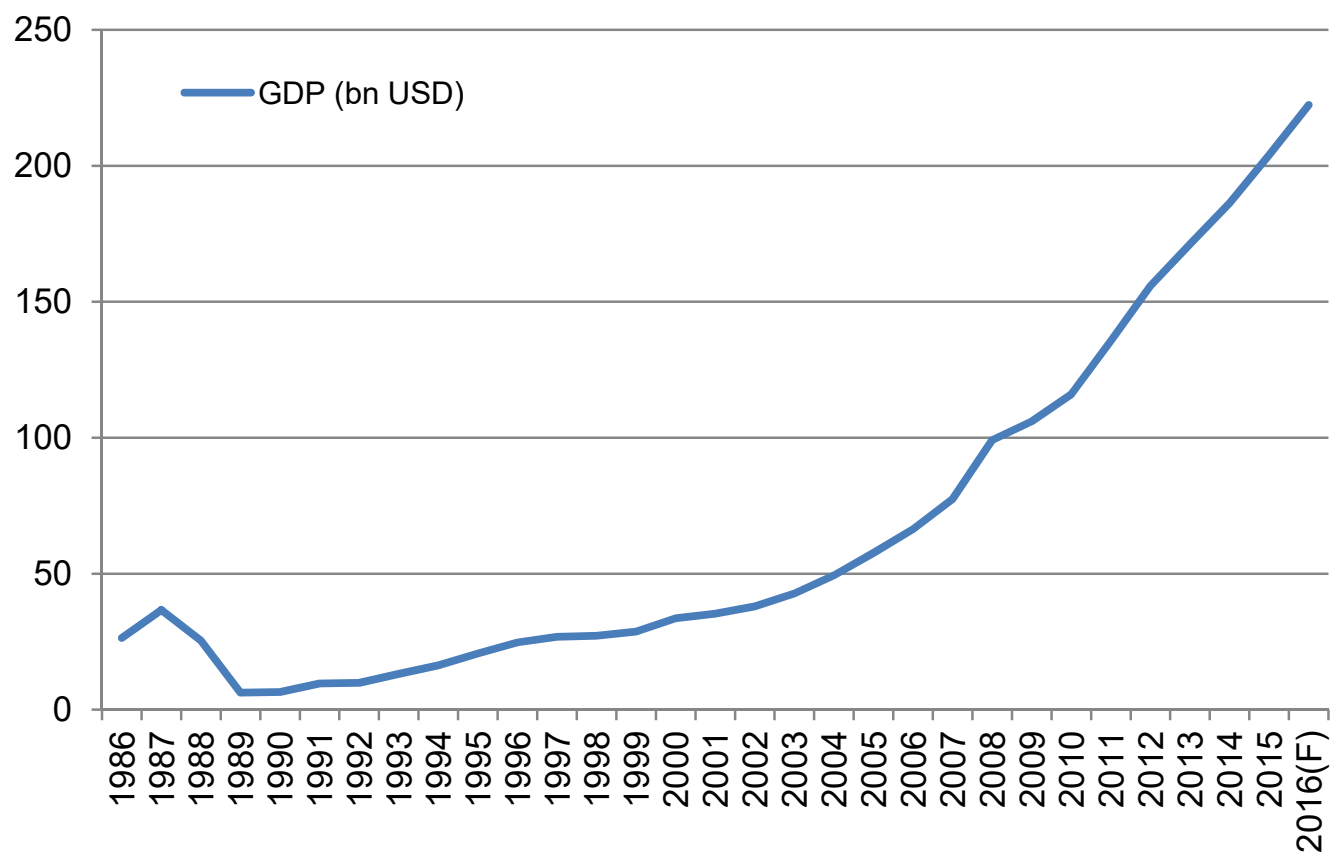

Source: Vuong 2010; ADB 2014/2015.

In 2015, GDP per capita of US $\$ 2,282$ made Vietnam a lower middle-income country. Households have more money to spend and invest as the domestic savings ratio remains high, approximately $30 \%$. The improved savings rate, in turn, helps to counter future economic shocks (Sepehri \& Akram-Lodhi 2005).

Figure 2. Gross domestic savings ratio, 1993-2014 


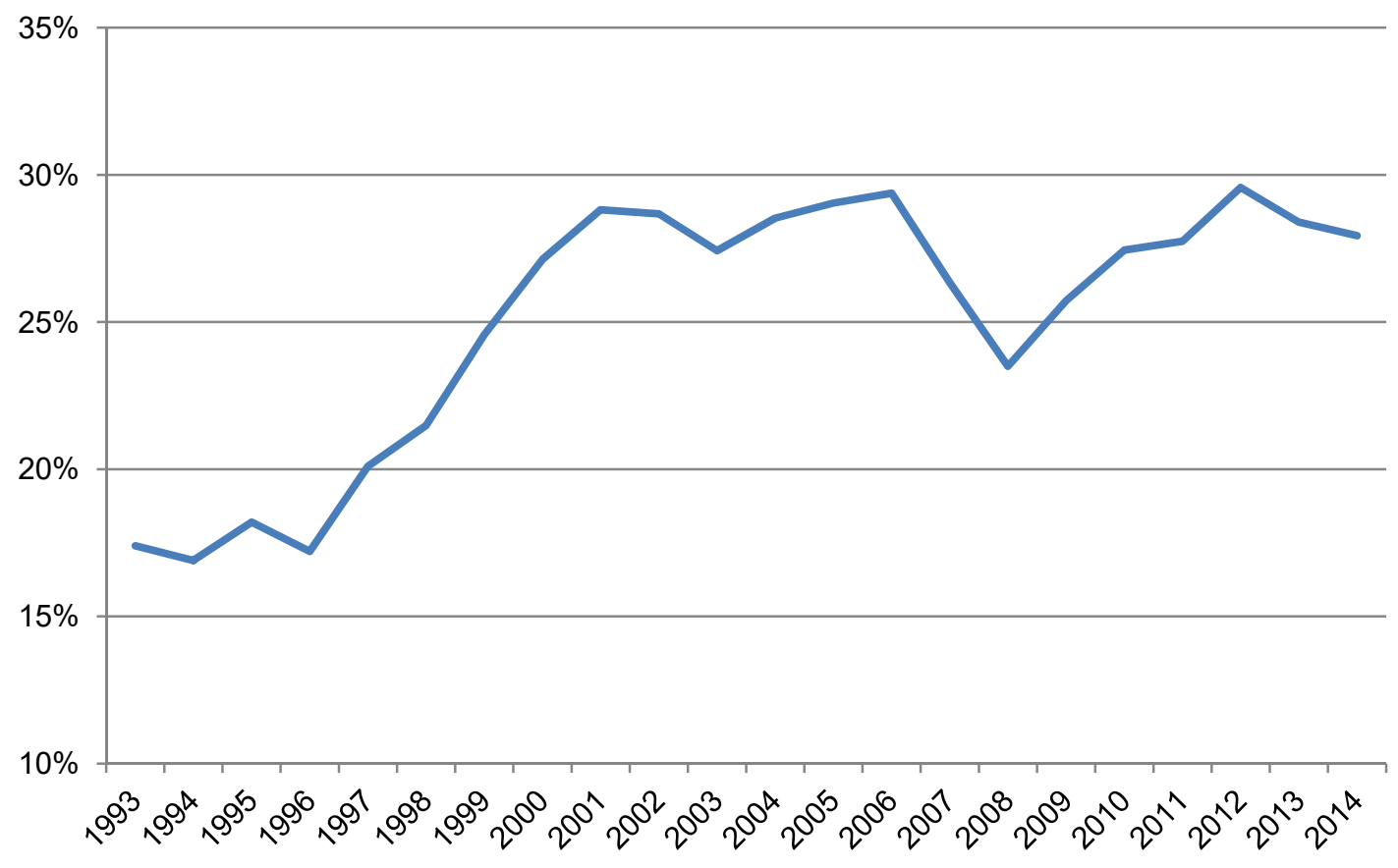

Foreign direct investments (FDI) also facilitated transformations with financial resources, technologies, markets, and new business methods. The stock of FDI-capital realizations by 2015 totaled approximately US $\$ 139$ billion (Table 1).

Table 1. FDI Statistics, 1988-2015

\begin{tabular}{|lrrr|}
\hline Year & $\begin{array}{c}\text { Number of } \\
\text { Projects }\end{array}$ & $\begin{array}{c}\text { Registered } \\
\text { Capital }\end{array}$ & \multicolumn{1}{c|}{$\begin{array}{c}\text { Disbursed } \\
\text { Capital }\end{array}$} \\
\hline $1988-1990$ & 211 & $1,603.5$ & N/A \\
1991 & 152 & $1,284.4$ & 428.5 \\
1992 & 196 & $2,077.6$ & 574.9 \\
1993 & 274 & $2,829.8$ & $1,117.5$ \\
1994 & 372 & $4,262.1$ & $2,240.6$ \\
1995 & 415 & $7,925.2$ & $2,792.0$ \\
1996 & 372 & $9,635.3$ & $2,938.2$ \\
1997 & 349 & $5,955.6$ & $3,277.1$ \\
1998 & 285 & $4,873.4$ & $2,372.4$ \\
1999 & 327 & $2,282.5$ & $2,528.3$ \\
2000 & 391 & $2,762.8$ & $2,398.7$ \\
2001 & 555 & $3,265.7$ & $2,225.6$ \\
2002 & 808 & $2,993.4$ & $2,884.7$ \\
2003 & 791 & $3,172.7$ & $2,723.3$ \\
2004 & 811 & $4,534.3$ & $2,708.4$ \\
2005 & 970 & $6,840.0$ & $3,300.5$ \\
2006 & 987 & $12,004.5$ & $4,100.4$ \\
2007 & 1,544 & $21,348.8$ & $8,034.1$ \\
\hline
\end{tabular}




\begin{tabular}{|llll|}
\hline 2008 & 1,171 & $71,726.8$ & $11,500.2$ \\
2009 & 1,208 & $23,107.5$ & $10,000.5$ \\
2010 & 1,237 & $19,886.8$ & $11,000.3$ \\
2011 & 1,191 & $15,618.7$ & $11,000.1$ \\
2012 & 1,287 & $16,348.0$ & $10,046.6$ \\
2013 & 1,530 & $22,352.2$ & $11,500.0$ \\
2014 & 1,843 & $21,921.7$ & $12,500.0$ \\
2015 & 2,013 & $22,760.0$ & $14,500.0$ \\
\hline \multicolumn{4}{l}{ Source: GSO. Capital unit: million US\$. } \\
\hline
\end{tabular}

The financial markets had been virtually inexistent before 1990 although money, bank deposits, loan transactions did exist. With VFS reforms this component economy has grown up fast (Román 1995; Vuong 2010).

Figure 3. National Reserve (forex/gold; million US\$)

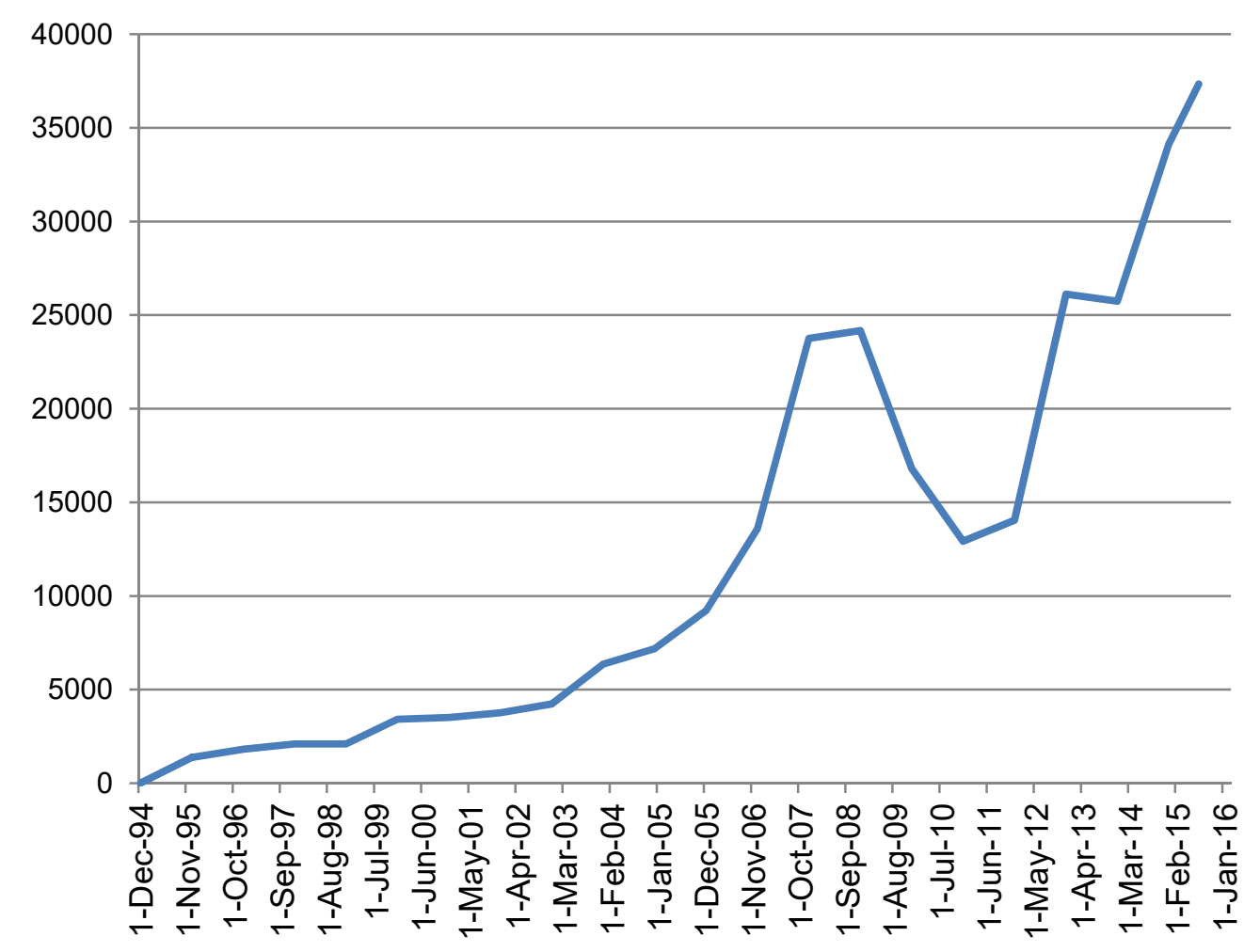

Source: WB-WDI/SBV/Author's estimate.

Over time, VFS has been able to build up the national reserve that is regarded as "coussin-de-sécurité" against economic shocks that tend to occur frequently in an open emerging economy (see Fig. 3).

Governance framework 
Along the process of reforms, new regulations constitute the governance framework required for achieving VFS's strategic goals. The transition period has made this task of lawmaking and enforcement particularly challenging. There are different promulgators in Vietnam: the Politburo, National Assembly (NA), President, Government (Govt) and Prime Minister (PM), Ministries and ministerial-level agencies. Legal documents consist of resolution; laws; circular/decision/directive; and, decree.

Table 2. Legal documents governing the Vietnamese financial system:

\begin{tabular}{|c|c|c|c|c|c|}
\hline & 2007 & 2008 & 2009 & 2010 & 2011 \\
\hline By Govt and PM & 46 & 36 & 16 & 6 & 11 \\
\hline By SBV & 94 & 106 & 103 & 35 & 57 \\
\hline By NA & 1 & 1 & 0 & 6 & 3 \\
\hline Other Ministries & 3 & 34 & 3 & 9 & 4 \\
\hline & 2012 & 2013 & 2014 & 2015 & $2016-2 \mathrm{M}$ \\
\hline By Govt and PM & 16 & 3 & 6 & 2 & 0 \\
\hline By SBV & 50 & 49 & 87 & 55 & 23 \\
\hline By NA & 4 & 0 & 0 & 0 & 0 \\
\hline Other Ministries & 16 & 0 & 1 & 3 & 0 \\
\hline
\end{tabular}

The regulatory framework that governs VFS has been built over the past ten years (Table 2). The State Bank of Vietnam (SBV) has issued a relatively large number of regulations. Documents listed in Table 3 are important for regulating a large spectrum of financial activities.

Table 3. Key financial regulations

\begin{tabular}{|c|c|c|c|}
\hline Subject & Docs & Date & Remarks \\
\hline \multirow{2}{*}{ Central bank } & $\begin{array}{l}\text { Law } \\
46 / 2010 / Q H 12\end{array}$ & $\begin{array}{l}16 / 06 / 2010 \\
\text { (NA) }\end{array}$ & Law on the State Bank of Vietnam (SBV) \\
\hline & $\begin{array}{l}\text { Decree } \\
96 / 2008 / \mathrm{ND}-\mathrm{CP}\end{array}$ & $\begin{array}{l}\text { 26/08/2008 } \\
\text { (Govt) }\end{array}$ & $\begin{array}{l}\text { Functions, responsibilities, and structure of } \\
\text { SBV. }\end{array}$ \\
\hline \multirow{7}{*}{$\begin{array}{l}\text { Credit } \\
\text { institutions }\end{array}$} & $\begin{array}{l}\text { Decree } \\
10 / 2011 / \mathrm{ND}-\mathrm{CP}\end{array}$ & $\begin{array}{l}\text { 26/01/2011 } \\
\text { (Govt) }\end{array}$ & $\begin{array}{l}\text { Amending/supplementing Decree } \\
\text { 141/2006/ND-CP. }\end{array}$ \\
\hline & $\begin{array}{l}\text { Circular } \\
\text { 03/2007/TT- } \\
\text { NHNN }\end{array}$ & $\begin{array}{l}05 / 06 / 2007 \\
\text { (SBV) }\end{array}$ & Implementing Decree 22/2006/ND-CP. \\
\hline & $\begin{array}{l}\text { Decree } \\
141 / 2006 / \mathrm{ND}-\mathrm{CP} \\
\end{array}$ & $\begin{array}{l}22 / 11 / 2006 \\
\text { (Govt) }\end{array}$ & Legal capital levels of credit institutions \\
\hline & $\begin{array}{l}\text { Directive } \\
\text { 02/2006/CT- } \\
\text { NHNN }\end{array}$ & $\begin{array}{l}23 / 05 / 2006 \\
\text { (SBV) }\end{array}$ & Measures to mitigate credit risks. \\
\hline & $\begin{array}{l}\text { Decree } \\
22 / 2006 / \text { ND-CP }\end{array}$ & $\begin{array}{l}28 / 02 / 2006 \\
\text { (Govt) }\end{array}$ & $\begin{array}{l}\text { On organization/operation of FOCBs in } \\
\text { Vietnam }\end{array}$ \\
\hline & $\begin{array}{l}\text { Decree } \\
109 / 2005 / \mathrm{ND}-\mathrm{CP}\end{array}$ & $\begin{array}{l}24 / 08 / 2005 \\
\text { (Govt) }\end{array}$ & Amending Decree no. 89/1999/ND-CP. \\
\hline & $\begin{array}{l}\text { Decree } \\
89 / 1999 / \mathrm{ND}-\mathrm{CP}\end{array}$ & $\begin{array}{l}01 / 09 / 1999 \\
\text { (Govt) }\end{array}$ & On deposit insurance. \\
\hline \multirow{2}{*}{$\begin{array}{l}\text { Non-bank } \\
\text { financial } \\
\text { companies } \\
\text { (NBFIs) }\end{array}$} & $\begin{array}{l}\text { Decree } \\
81 / 2008 / \mathrm{ND}-\mathrm{CP}\end{array}$ & $\begin{array}{l}29 / 07 / 2008 \\
\text { (Govt) }\end{array}$ & Amending Decree No. 79/2002/ND-CP. \\
\hline & $\begin{array}{l}\text { Decree } \\
79 / 2002 / \mathrm{ND}-\mathrm{CP}\end{array}$ & $\begin{array}{l}04 / 10 / 2002 \\
\text { (Govt) }\end{array}$ & Regulations on finance companies. \\
\hline
\end{tabular}




\begin{tabular}{|c|c|c|c|}
\hline \multirow{10}{*}{$\begin{array}{l}\text { Insurance } \\
\text { companies }\end{array}$} & $\begin{array}{l}\text { Law } \\
61 / 2010 / \mathrm{QH} 12\end{array}$ & $\begin{array}{l}24 / 11 / 2010 \\
\text { (NA) }\end{array}$ & $\begin{array}{l}\text { Amending/supplementing the insurance } \\
\text { business law. }\end{array}$ \\
\hline & $\begin{array}{l}\text { Decree } \\
62 / 2009 / \mathrm{ND}-\mathrm{CP}\end{array}$ & $\begin{array}{l}27 / 07 / 2009 \\
\text { (Govt) }\end{array}$ & $\begin{array}{l}\text { Detailing/guiding the Law on Health } \\
\text { Insurance. }\end{array}$ \\
\hline & $\begin{array}{l}\text { Law } \\
25 / 2008 / Q H 12\end{array}$ & $\begin{array}{l}14 / 11 / 2008 \\
\text { (NA) }\end{array}$ & Law on health insurance. \\
\hline & $\begin{array}{l}\text { Decree } \\
114 / 2008 / \mathrm{ND}-\mathrm{CP}\end{array}$ & $\begin{array}{l}03 / 11 / 2008 \\
\text { (Govt) }\end{array}$ & $\begin{array}{l}\text { Implementing the Bankruptcy Law } \\
\text { applicable to financial institutions. }\end{array}$ \\
\hline & $\begin{array}{l}\text { Decree } \\
94 / 2008 / \mathrm{ND}-\mathrm{CP}\end{array}$ & $\begin{array}{l}22 / 08 / 2008 \\
\text { (Govt) }\end{array}$ & On Vietnam Social Insurance. \\
\hline & $\begin{array}{l}\text { Decision } \\
\text { 96/2007/QD-BTC }\end{array}$ & $\begin{array}{l}23 / 11 / 2007 \\
\text { (MOF) }\end{array}$ & $\begin{array}{l}\text { Ministry of Finance (MOF) promulgating the } \\
\text { regulation on universal life insurance } \\
\text { products. }\end{array}$ \\
\hline & $\begin{array}{l}\text { Decree } \\
46 / 2007 / \text { ND-CP }\end{array}$ & $\begin{array}{l}27 / 03 / 2007 \\
\text { (Govt) }\end{array}$ & $\begin{array}{l}\text { Financial regulations on insurance and } \\
\text { broker firms. }\end{array}$ \\
\hline & $\begin{array}{l}\text { Decrees } \\
\text { 43/2001/ND-CP; } \\
\text { 42/2001/ND-CP }\end{array}$ & $\begin{array}{l}01 / 08 / 2001 \\
\text { (Govt) }\end{array}$ & $\begin{array}{l}\text { \#43: Financial regime applicable to } \\
\text { insurance and brokerage firms; \#42: } \\
\text { Implementing the Law on Insurance } \\
\text { Business. }\end{array}$ \\
\hline & $\begin{array}{l}\text { Law } \\
24 / 2000 / \mathrm{QH} 10\end{array}$ & $\begin{array}{l}09 / 12 / 2000 \\
\text { (NA) }\end{array}$ & Law on Insurance Business. \\
\hline & $\begin{array}{l}\text { Circular } \\
\text { 03/2000/TT- } \\
\text { NHNN5 }\end{array}$ & $\begin{array}{l}16 / 03 / 2000 \\
(\mathrm{SBV})\end{array}$ & Implementing Decree 89/1999/ND-CP. \\
\hline \multirow{4}{*}{$\begin{array}{l}\text { Securities } \\
\text { companies }\end{array}$} & $\begin{array}{l}\text { Law } \\
62 / 2010 / \mathrm{QH} 12\end{array}$ & $\begin{array}{l}24 / 11 / 2010 \\
\text { (NA) }\end{array}$ & $\begin{array}{l}\text { Amending/supplementing the Law on } \\
\text { Securities. }\end{array}$ \\
\hline & $\begin{array}{l}\text { Decree } \\
114 / 2008 / \mathrm{ND}-\mathrm{CP}\end{array}$ & $\begin{array}{l}03 / 11 / 2008 \\
\text { (Govt) }\end{array}$ & $\begin{array}{l}\text { Implementing the Bankruptcy Law } \\
\text { applicable to FIs. }\end{array}$ \\
\hline & $\begin{array}{l}\text { Decisions } \\
\text { 27/2007/QD-BTC; } \\
\text { 55/2004/QD-BTC }\end{array}$ & $\begin{array}{l}24 / 04 / 2007 \\
17 / 06 / 2004 \\
\text { (MOF) }\end{array}$ & Regulation on securities companies \\
\hline & $\begin{array}{l}\text { Decision } \\
78 / 2000 / Q D- \\
\text { UBCK }\end{array}$ & $\begin{array}{l}29 / 12 / 2000 \\
(\mathrm{SSC})\end{array}$ & $\begin{array}{l}\text { The State Securities Commission (SSC) } \\
\text { amending the regulation on securities } \\
\text { companies. }\end{array}$ \\
\hline \multirow{3}{*}{$\begin{array}{l}\text { Investment } \\
\text { funds }\end{array}$} & $\begin{array}{l}\text { Decree } \\
138 / 2007 / \mathrm{ND}-\mathrm{CP}\end{array}$ & $\begin{array}{l}28 / 08 / 2007 \\
\text { (Govt) }\end{array}$ & $\begin{array}{l}\text { Regulation on local development investment } \\
\text { funds. }\end{array}$ \\
\hline & $\begin{array}{l}\text { Decisions: } \\
\text { 30/2006/QD-BTC; } \\
\text { 71/2005/QD-BTC; } \\
\text { 63/2005/QD-BTC; } \\
\text { 73/2004/QD-BTC }\end{array}$ & $\begin{array}{l}\text { 12/05/2006; } \\
\text { 21/10/2005; } \\
\text { 14/09/2005; } \\
03 / 09 / 2004 ; \\
\text { (MOF) }\end{array}$ & $\begin{array}{l}\text { Supplementing/amending the regulation on } \\
\text { securities investment funds and fund } \\
\text { management companies. }\end{array}$ \\
\hline & $\begin{array}{l}\text { Decision } \\
\text { 05/1998/QD- } \\
\text { UBCK3 }\end{array}$ & $\begin{array}{l}13 / 10 / 1998 \\
(\mathrm{SSC})\end{array}$ & $\begin{array}{l}\text { Regulation on securities investment funds } \\
\text { and fund management companies. }\end{array}$ \\
\hline \multirow{3}{*}{$\begin{array}{l}\text { Leasing } \\
\text { companies }\end{array}$} & $\begin{array}{l}\text { Decree } \\
\text { 95/2008/ND-CP }\end{array}$ & $\begin{array}{l}25 / 08 / 2008 \\
\text { (Govt) }\end{array}$ & $\begin{array}{l}\text { Amending/supplementing Decree } \\
16 / 2001 / \mathrm{ND}-\mathrm{CP} \text {. }\end{array}$ \\
\hline & $\begin{array}{l}\text { Directive } \\
01 / 2007 / \text { CT- } \\
\text { NHNN }\end{array}$ & $\begin{array}{l}06 / 03 / 2007 \\
\text { (SBV) }\end{array}$ & $\begin{array}{l}\text { Reorganizing operation of financial leasing } \\
\text { companies. }\end{array}$ \\
\hline & $\begin{array}{l}\text { Circular } \\
\text { 08/2006/TT- } \\
\text { NHNN } \\
\end{array}$ & $\begin{array}{l}12 / 10 / 2006 \\
(\mathrm{SBV})\end{array}$ & $\begin{array}{l}\text { Guiding syndicated financial leasing activities } \\
\text { under Decree 16/2001/ND-CP. }\end{array}$ \\
\hline
\end{tabular}




\begin{tabular}{|l|l|l|l|}
\hline & Decree & $02 / 05 / 2001$ & On financial leasing companies. \\
& $16 / 2001 / \mathrm{ND}-\mathrm{CP}$ & (Govt) & \\
\cline { 2 - 4 } & Decree & $09 / 10 / 1995$ & Provisional regulations on financial leasing \\
& $64 / \mathrm{CP}$ & (Govt) & companies. \\
\hline
\end{tabular}

Studying the history and contents of these regulations can help us learn a great deal about how the financial system has developed over the course of time.

\section{The contemporary history}

Important events of the history of VFS are summarized in Table 4, starting the National Bank of Vietnam - the predecessor of SBV—established on May 6, 1951, following President Ho Chi Minh's Ordinance 15/SL to facilitate the rebuilding of the economy and preparing for the resistance war against the French troops. The main tasks of the NBV then were to (Vuong 2010):

i) issue notes;

ii) regulate circulation of money and the credit to support business of industry and agriculture;

iii) mobilize the free means of the population;

iv) administer the state treasury;

v) manage forex affairs and settlements with foreign countries;

vi) direct the currency and credit policy

Table 4. Milestones of the financial system

\begin{tabular}{|l|l|l|}
\hline Year & Events & Remarks \\
\hline 1951 & Establishing of National Bank of Vietnam & The monobank system. \\
\hline 1957 & $\begin{array}{l}\text { Establishing of Vietnam Construction } \\
\text { Bank }\end{array}$ & Predecessor of BIDV \\
\hline 1962 & Vietcombank & $\begin{array}{l}\text { Vietcombank as a spinoff from Forex } \\
\text { Control Department of the central bank }\end{array}$ \\
\hline $1985-86$ & $\begin{array}{l}\text { The devastating economic crisis, } \\
\text { hyperinflation, currency devaluation }\end{array}$ & $\begin{array}{l}\text { Failure of the so-called Price-Wage- } \\
\text { Currency experiment }\end{array}$ \\
\hline \multicolumn{2}{|c|}{ Post-Doi Moi } \\
\hline 1986 & $\begin{array}{l}\text { Launching Doi Moi at the Sixth National } \\
\text { Congress of the Communist Party of } \\
\text { Vietnam. }\end{array}$ & $\begin{array}{l}\text { Recognizing/legalizing different types of } \\
\text { economic ownership in the Vietnamese } \\
\text { economy. }\end{array}$ \\
\hline 1987 & The Law on Foreign Investment passed & \\
\hline $1986-88$ & Hyperinflation & $\begin{array}{l}\text { 3-digit inflation: 748\% (1986), 223\% } \\
\text { (1987) and 394\% (1988). }\end{array}$ \\
\hline $1988-89$ & $\begin{array}{l}\text { Banking reforms started with the birth of } \\
\text { a two-tiered banking system. }\end{array}$ & $\begin{array}{l}\text { 26/3/1988: Decree 53/HDBT laying the } \\
\text { foundation to "transform the banking } \\
\text { system to commercial operations". SBV } \\
\text { was consolidated to manage the } \\
\text { monetary, credit and credit institutions. } \\
\text { State Treasury Department was spun off } \\
\text { from the central bank. Four SOCBs } \\
\text { focused on commercial specializations. } \\
\text { Positive real interest rate policy }\end{array}$ \\
\hline
\end{tabular}




\begin{tabular}{|c|c|c|}
\hline & & implemented. \\
\hline 1990 & Chain collapse of credit cooperatives. & $\begin{array}{l}\text { Thanh Huong credit scandal broke out in } \\
\text { March } 1990 \text { leading to the arrest of well- } \\
\text { known entrepreneur Nguyen Van Muoi } \\
\text { Hai who had mobilized money from } \\
\text { masses through a large system of } 900 \\
\text { money-receiving outlets, offering } 12-15 \% \\
\text { interest rate/month during } 1987-1989 \text {. A } \\
\text { chain collapse occurred, causing an } \\
\text { irrecoverable loss of VND37bn. (Using } \\
\text { average US\$:VND forex rate of } 2,500 \text {, this } \\
\text { loss was } \sim \text { US } \$ 14.8 \text { million or } 0.235 \% \\
\text { GDP of Vietnam in 1989.) }\end{array}$ \\
\hline 1990 & $\begin{array}{l}\text { The State approved two Ordinances on } \\
\text { SBV and commercial banking system. }\end{array}$ & $\begin{array}{l}\text { Decision 403-CT to transform state- } \\
\text { owned specialization banks into SOCBs: } \\
\text { BIDV, Vietcombank, Incombank, and } \\
\text { Agribank. }\end{array}$ \\
\hline 1992 & Amended Constitution. & $\begin{array}{l}\text { Legalizing and protecting private } \\
\text { property rights. }\end{array}$ \\
\hline 1991-92 & $\begin{array}{l}\text { First JSCBs/FOCBs licensed. First } \\
\text { Western investment funds and unit } \\
\text { trusts in Vietnam. }\end{array}$ & Law on Credit Institutions 1990. \\
\hline 1991-92 & $\begin{array}{l}\text { Financing arrangement by France and } \\
\text { Japan. U.S. Govt signaled warming } \\
\text { relations, allowing American firms to set } \\
\text { up offices and do contract works for FIEs } \\
\text { in Vietnam. }\end{array}$ & $\begin{array}{l}\text { US } \$ 55 \text { million grant and US } \$ 85 \mathrm{mn} \text { loans } \\
\text { arranged for Vietnam to pay off its } \\
\text { US } \$ 142 \mathrm{mn} \text { arrears to IMF since } 1985 \text {. }\end{array}$ \\
\hline 1993 & $\begin{array}{l}\text { IMF restored Vietnam's borrowing } \\
\text { eligibility after an 8-year suspension. }\end{array}$ & $\begin{array}{l}\text { Vietnam formally settled arrears to IMF in } \\
\text { Oct. The Fund approved a US } \$ 233 \mathrm{mn} \\
\text { loan, following President Clinton's } \\
\text { decision to ease 2-decade economic } \\
\text { sanctions on Vietnam. }\end{array}$ \\
\hline 1993 & $\begin{array}{l}\text { WB granted loans of US } \$ 320 \mathrm{mn} \text { through } \\
\text { IDA facilities, and ADB US } \$ 76 \mathrm{mn} \text {. }\end{array}$ & $\begin{array}{l}\text { After Vietnam paid off her US } \$ 13.5 \mathrm{mn} \\
\text { arrears to ADB. }\end{array}$ \\
\hline $1992-93$ & $\begin{array}{l}\text { The historic visit of François Mitterrand. } \\
\text { ODA inflows. }\end{array}$ & $\begin{array}{l}\text { French ODA: US\$33mn (1992), US\$65mn } \\
\text { (1993). PM Vo Van Kiet visited South } \\
\text { Korea and Australia, securing ODA grants } \\
\text { US } \$ 50 \mathrm{mn} \text { and AU } \$ 100 \mathrm{mnn} \text {. }\end{array}$ \\
\hline 1994 & $\begin{array}{l}\text { The lifting of the U.S. trade embargo on } \\
\text { Vietnam. }\end{array}$ & Clinton's administration. \\
\hline 1995 & $\begin{array}{l}\text { Normalization of diplomatic relations } \\
\text { with the United States. Becoming a } \\
\text { member of ASEAN (Association of } \\
\text { Southeast Asian Nations). }\end{array}$ & $\begin{array}{l}\text { Marking the process of reintegrating into } \\
\text { the world economy. IMF, WB, and ADB } \\
\text { opened offices. Donors community has } \\
\text { become active. }\end{array}$ \\
\hline 1997 & $\begin{array}{l}\text { The collapse of a group of } 50 \text { companies } \\
\text { related to Minh Phung-Epco alliance. }\end{array}$ & $\begin{array}{l}\text { Irrecoverable loss of VND 3,000 billion } \\
\text { during 1993-96. They mobilized VND } \\
6,000 \text { billion, US } \$ 32 \text { million } 400 \text { credit } \\
\text { contracts with six banks. }\end{array}$ \\
\hline 1997-98 & Asian currency/financial crisis. & $\begin{array}{l}\text { Vietnam issued Brady Bonds for settling } \\
\text { US } \$ 553 \mathrm{mn} \text { distressed loans in } 1998 .\end{array}$ \\
\hline $2000-01$ & $\begin{array}{l}\text { Inauguration of the first stock market: } \\
\text { HSTC (predecessor of Ho Chi Minh City } \\
\text { Stock Exchange, HOSE). }\end{array}$ & $\begin{array}{l}\text { Started with four privatized SOEs. Ultra- } \\
\text { thin trading. Primitive products. First } \\
\text { collapse in May 2001: the first stock } \\
\text { market collapse before the market was }\end{array}$ \\
\hline
\end{tabular}




\begin{tabular}{|c|c|c|}
\hline & & born. \\
\hline 2005 & $\begin{array}{l}\text { Opening HaSTC (today's Hanoi Stock } \\
\text { Exchange/HNX). The 2nd Vietnamese } \\
\text { government bond offering since Doi Moi. }\end{array}$ & $\begin{array}{l}\text { US } \$ 750 \mathrm{~m} \text { international bond issue; the } \\
\text { rate of } 7.125 \% \text {. }\end{array}$ \\
\hline 2006 & $\begin{array}{l}\text { Stock prices surged, leading to over- } \\
\text { optimistic sentiment and high levels of } \\
\text { P/E. }\end{array}$ & $\begin{array}{l}\text { Following "bullish reports" about } \\
\text { prospects of Vietnam stock market. }\end{array}$ \\
\hline \multicolumn{3}{|c|}{ Post-WTO } \\
\hline 2007 & Vietnam joined WTO. & $\begin{array}{l}\text { US\$10.2b FPI flooded during 2006-07 } \\
\text { without proper sterilization. }\end{array}$ \\
\hline 2007 & $\begin{array}{l}\text { Vietnam Stock Market reached the record } \\
\text { high. }\end{array}$ & HOSE VN-Index: 1,171 on $12 / 3 / 2007$. \\
\hline $2007-08$ & 2-digit inflation recurred. & 12.6\% (2007); $19.9 \%$ (2008). \\
\hline 2008-09 & $\begin{array}{l}\text { The stock market in turmoil. USD } 6 \\
\text { billion stimulus package released, } \\
\text { 2008Q4-2009Q1. }\end{array}$ & $\begin{array}{l}\text { Govt Decision 131/QD-TTg, subsidizing } \\
\text { borrowings costs by } 4 \% \text {-max. }\end{array}$ \\
\hline 2010 & $\begin{array}{l}\text { Vinashin's default on its financial } \\
\text { obligations to international lenders. }\end{array}$ & $\begin{array}{l}\text { Vinashin's collapse caused an } \\
\text { irrecoverable loss estimated at US } \$ 4.4 \\
\text { billion. }\end{array}$ \\
\hline 2011 & $\begin{array}{l}\text { The arrest of Huynh Thi Huyen Nhu, a } \\
\text { banker. }\end{array}$ & $\begin{array}{l}\text { Largest financial fraud, causing an } \\
\text { estimated loss of VND 3,300b. } 4 \text { banks, } 9 \\
\text { companies involved during 2007-2011. }\end{array}$ \\
\hline $2011-12$ & 2-digit inflation recurred. & 11.75\% (2011); 18.13\% (2012). \\
\hline 2011 & $\begin{array}{l}\text { Struggled to control credit growth }<20 \% \text {, } \\
\text { and M2 growth }<16 \% \text {. }\end{array}$ & $\begin{array}{l}\text { Policy rate jumped from } 9 \% \text { to } 11 \% \\
(17 / 2 / 2011) \text {, then } 12 \%(1 / 5 / 2011) \text {. }\end{array}$ \\
\hline 2012 & $\begin{array}{l}\text { The arrest of ACB finance mogul Nguyen } \\
\text { Duc Kien. Vinalines on the verge of } \\
\text { bankruptcy, former CEO and Chair } \\
\text { arrested. }\end{array}$ & $\begin{array}{l}\text { 6/2012: SBV removed interest rate cap } \\
\text { for commercial loans, liberalizing interest } \\
\text { rates. }\end{array}$ \\
\hline 2013 & The launch of VAMC. & $\begin{array}{l}\text { Dealing with bad debt problems in the } \\
\text { banking system. Back to restrictive } \\
\text { monetary policy. }\end{array}$ \\
\hline 2014 & External debt $\sim$ US $\$ 72 \mathrm{bn}$. & $38.6 \%$ GDP. \\
\hline 2015 & State budget showed signs of stress. & $\begin{array}{l}\text { MPI Minister stated needs of renewed } \\
\text { reforms. }\end{array}$ \\
\hline 2016 & AEC officially came into existence. & $\begin{array}{l}\text { ASEAN regional economy: } 660 \text {-million } \\
\text { population; US } \$ 2,500 \text { b GDP. }\end{array}$ \\
\hline
\end{tabular}

With Doi Moi and a two-tiered banking system, VFS has come into existence. Its early task was to fight late-1980s inflation. The battle was continuing well into the early 1990s. In the 2010s, once again inflation plagued the economy-see Fig. 4-and the battle was resumed, making VFS's members constantly vigilant.

Figure 4. Inflation vs. Growth (\% p.a.) 


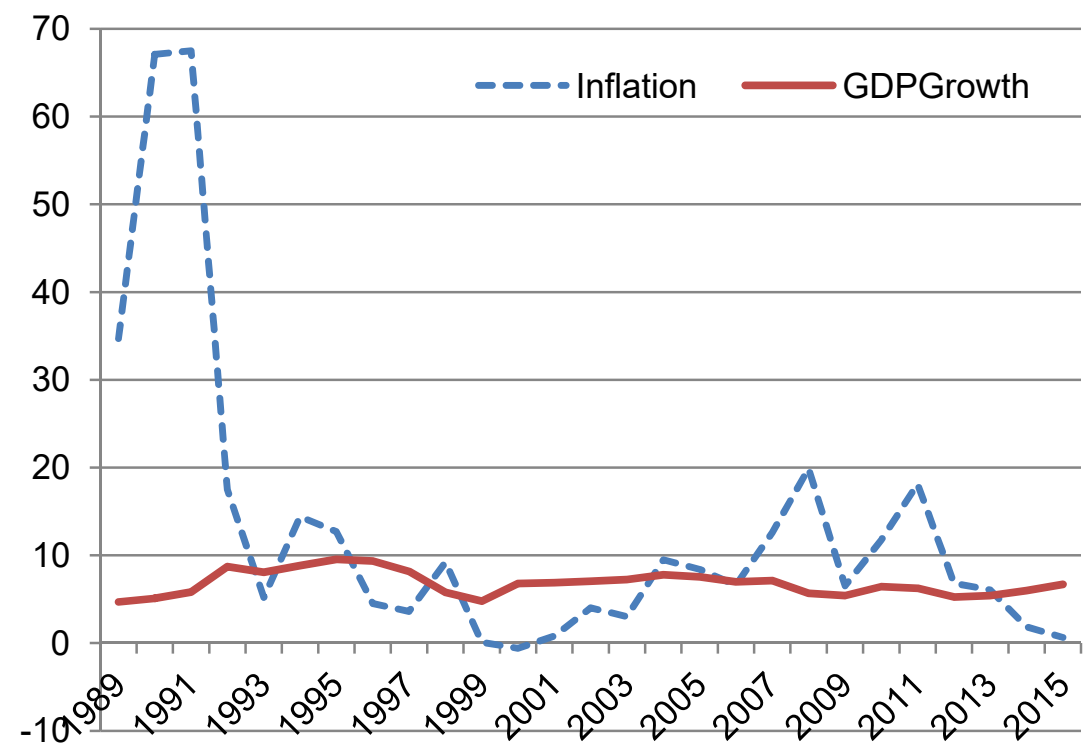

Data: General Statistics Office/GSO.

\section{Institutions-markets-instruments}

\section{Institutions}

The transformation from a centrally planned model to a market-oriented economy faced numerous hurdles due to economic disorders, virtually zero savings, hyperinflation, and heavy reliance on money printing. Institutions building process in VFS took place in this period.

Most important types of financial institutions are presented in Fig. 5. VFS has been bank-based, with $80 \%$ of financial intermediation conducted by a handful of powerful banks. But banks resources had been limited until the mid-2000s with the size of the banking sector being modest, M2/GDP $<80 \%$ (Fig. 6), while Thailand and Malaysia had M2/GDP>100\% in 2000 (ADB 2014). In 2015, the banking sector accounted for $92.25 \%$ of VFS's assets.

Figure 5. VFS's Structure 


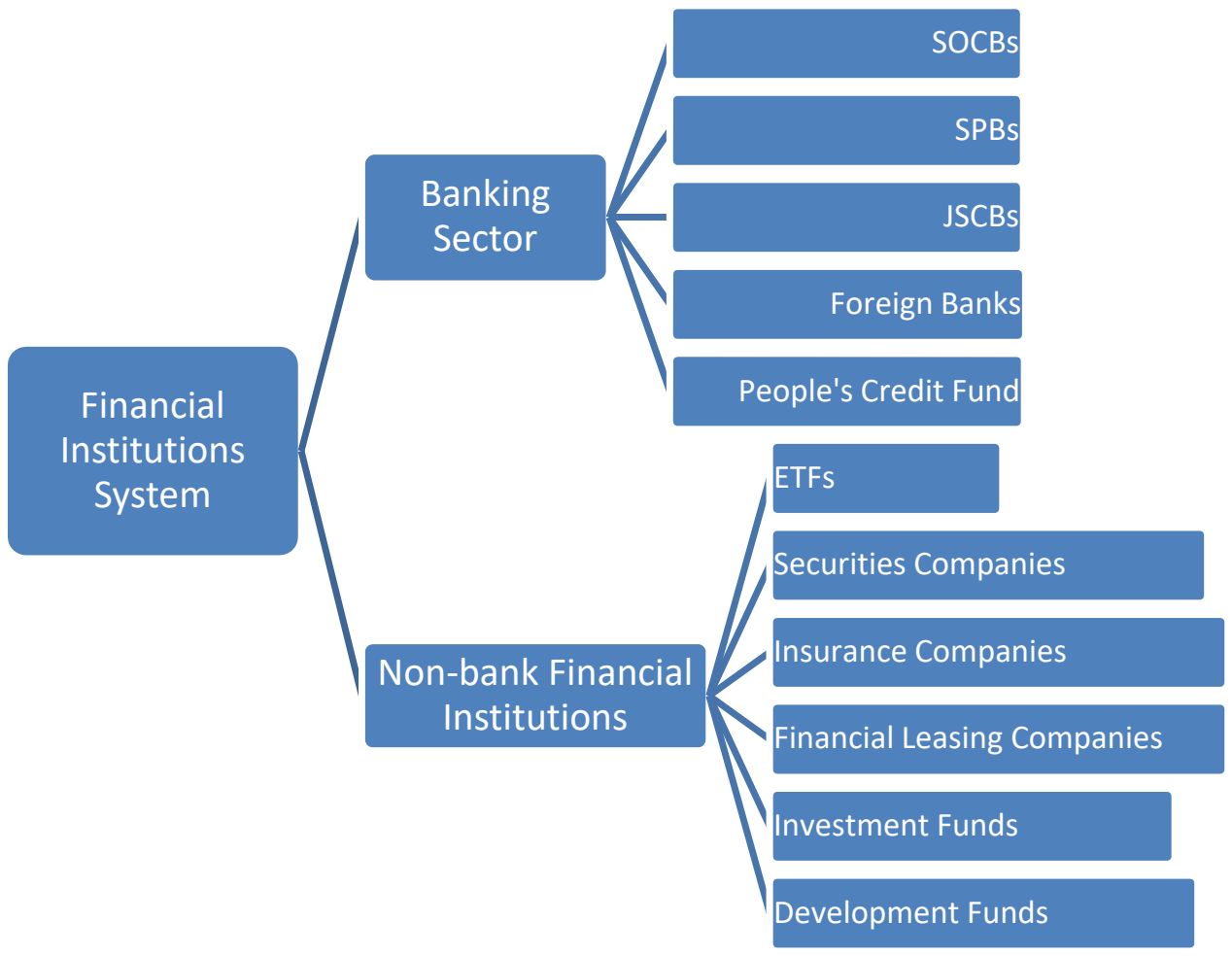

Correlated with the pace of inflation and economic expansion, the process of monetizing Vietnam's economy started in the early 1990s, and accelerated mid-2000s, when the equity market boomed, leading broad money supply (M2) to surge (see Fig. 6), standing at US\$267 billion at 2015 year-end.

Figure 6. M2/GDP during 1995-2015

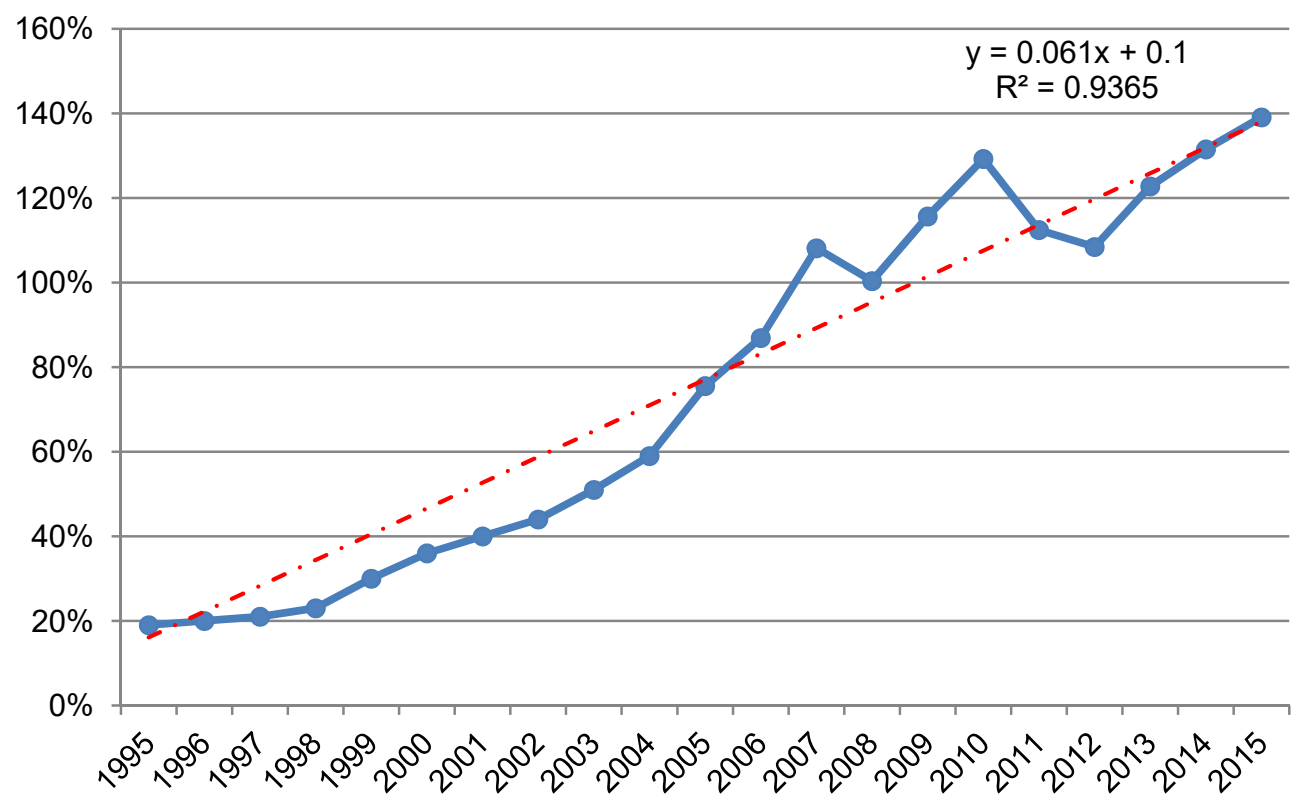

Sources: SBV, GSO, ADB, and author's estimates.[2] 
At the dawn of Doi Moi, 1986, total credit supply jumped by 1,897\% compared to that of 1976 , and by $326 \%$ of 1980 . By the end of 1990 , the total credit balance in the economy was 4,361\% of the 1986 amount (or, 63,789\% of the 1980 amount). Most counterinflation measures employed then were "situational reactions," not without negative consequences. Early adoption of the so-called monetary policy measures only arrived in 1991, having learned the market-based economic mechanism the hard way: slower money velocity could help weather hyperinflation, given certain economic conditions. A significant slowdown in credit growth then followed.

In the 1990s, this critically important task has been performed through a two-tiered banking system, with the State Bank of Vietnam in the command, and SOCBs/JSCBs playing the role of market performers. Credit growth went down to $70 \%$ in 1992 , and then to $27.5 \%$ in 1999, helping to reduce inflation level of almost $400 \%$ in 1988, down to $67.5 \%$ (1991), then $17.5 \%$ (1992), and then $0.1 \%$ (1999). Table 5 shows a changing institution composition over time.

Table 5. Financial institutions (FI) in Vietnam

\begin{tabular}{|l|r|r|r|r|r|}
\hline & \multicolumn{1}{|l|}{2001} & 2006 & 2008 & 2011 & 2016 \\
\hline SOCB & 5 & 5 & 5 & 4 & 4 \\
\hline SPB & 1 & 2 & 2 & 2 & 3 \\
\hline JSCB & 39 & 34 & 39 & 37 & 31 \\
\hline FOCBs - Branches & 26 & 31 & 44 & 48 & 55 \\
\hline FOCBs - 100\% & -- & -- & 2 & 5 & 6 \\
\hline FOCBs - JV & 4 & 5 & 6 & 6 & 7 \\
\hline People's Credit Fund (PCF) & 959 & -- & -- & 906 & -- \\
\hline NBFI - Financial Cos. & 7 & 8 & 22 & 18 & 17 \\
\hline NBFI - Financial Leasing Cos. & 8 & 8 & 12 & 12 & 11 \\
\hline Securities Companies & 8 & 15 & 87 & 105 & 81 \\
\hline Listed Companies (HSX/HNX) & 18 & $106 / 87$ & $175 / 168$ & $303 / 396$ & $312 / 388$ \\
\hline Securities Trading Accounts (million) & 0.009 & 0.106 & 0.53 & 1.19 & 1.48 \\
\hline Insurance Companies & 18 & 29 & 38 & 38 & 61 \\
\hline Note: SOCB: State-owned & & 29 & 38 & \\
\hline
\end{tabular}

Note: SOCB: State-owned commercial banks; JSCB: Joint-stock commercial bank; FOCB: Foreignowned commercial bank; JV: Joint-venture; NBFI: Non-bank financial institutions; SPB: Social policy bank.

Before PCFs, in 1990, about 300 credit cooperatives existed and mobilized a total amount of deposits worth US\$100 million, offering high-interest rates to depositors (De Vylder \& Fforde 1996). With an underdeveloped legal framework and a serious lack of risk management skills/knowledge, many just danced with wild fluctuations of inflation and interest rates, and finally went bankrupt. Their chain collapsed pushed hundreds of thousands in financial distress, causing a first nationwide post-Doi Moi financial crisis. It took nearly two decades for VFS to restore the populace's confidence.

PCFs resemble the credit cooperatives regarding social traits, but with market principles and joint-stock ownership. PCFs are particularly suitable for delivering rural microfinance. At present, the system of PCFs collectively has total equity of US\$140 million, and total assets US $\$ 3,545$ million. NBFIs, inclusive of PCFs, accounted for $8 \%$ of the total assets of the financial system in 2011, estimated at $200 \%$ of GDP.

\section{Markets and instruments}




\section{The banks, credit markets, and products:}

The banking industry has been dominated by four SOCBs: Vietcombank, BIDV, VietinBank, and Agribank. They are largest regarding total equity and assets (Fig. 7-8). The second 'family' consists of 31 JSCBs. Tier-1 JSCBs were founded during 1992-1993 with such names as ACB, Eximbank, Sacombank, VPBank, Techcombank...

Also, during 1990-1996, SBV issued licenses for 20 rural areas commercial banks. In the next ten years, only four new firms were licensed. Following Dec. 1557/QD-NHNN by SBV Governor on Aug 9, 2006, these rural banks, if satisfying financial and operational conditions set out by the central bank, may be 'converted' to normal JSCBs, which would be allowed to conduct business in urban areas. Most of them formed the tier-2, although some moved up the value chain and managed to expand and become more creditworthy and sizable, such as HDBank.

In the late 1990s, many commercial banks, both rural and urban, performed poorly causing a great deal of risk for the economy and bad debts to skyrocket. SBV had to put a number of banks in "special supervision", a de facto state of the moratorium so that restructuring-M\&A-dissolving operations could be performed without causing further damage to VFS. The number of commercial banks went down from 51 in 1997 to 39 in 2001.

After US-Vietnam BTA in 2001, and accession to WTO in 2007, Vietnam's banking market has opened to both FDI and FPI, leading to a surge in foreign banks' operation in the domestic market.

Figure 7. Bank's capital aggregate by ownership

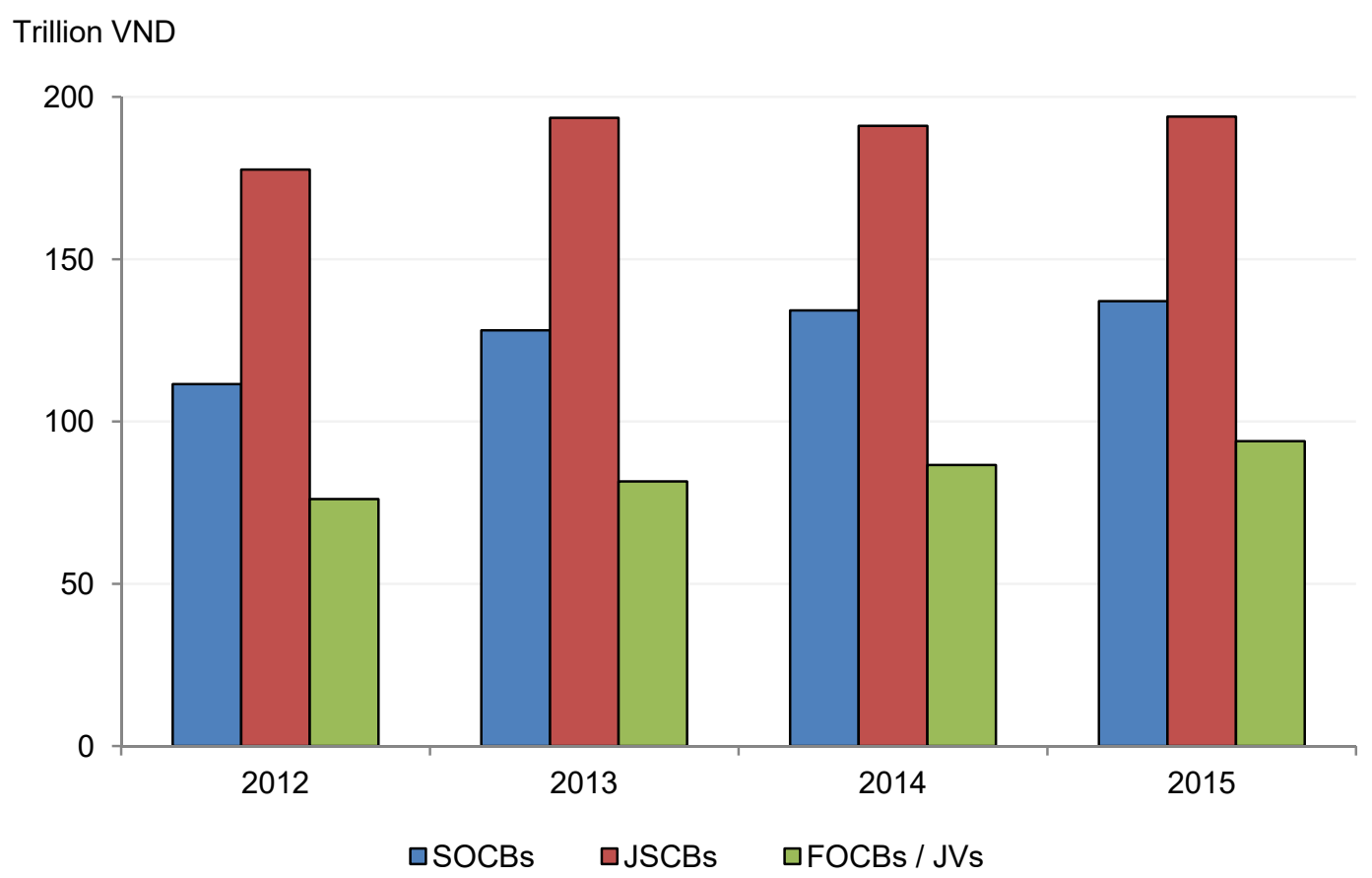

On April 19, 2005, SBV Governor issued decisions 457/2005/QD-NHNN requiring banks to maintain 8\% CAR defined by total equity to total risky assets, and 888/2005/QDNHNN (Jun 16, 2006) that each bank branch have a minimum of VND 20 billion. 
Banks frequently issued shares to shore up their capital base. Thus by the end of 2006, most commercial banks had equity three times of the 2004 level.

Figure 8. Changes in banks' total assets

Trillion VND

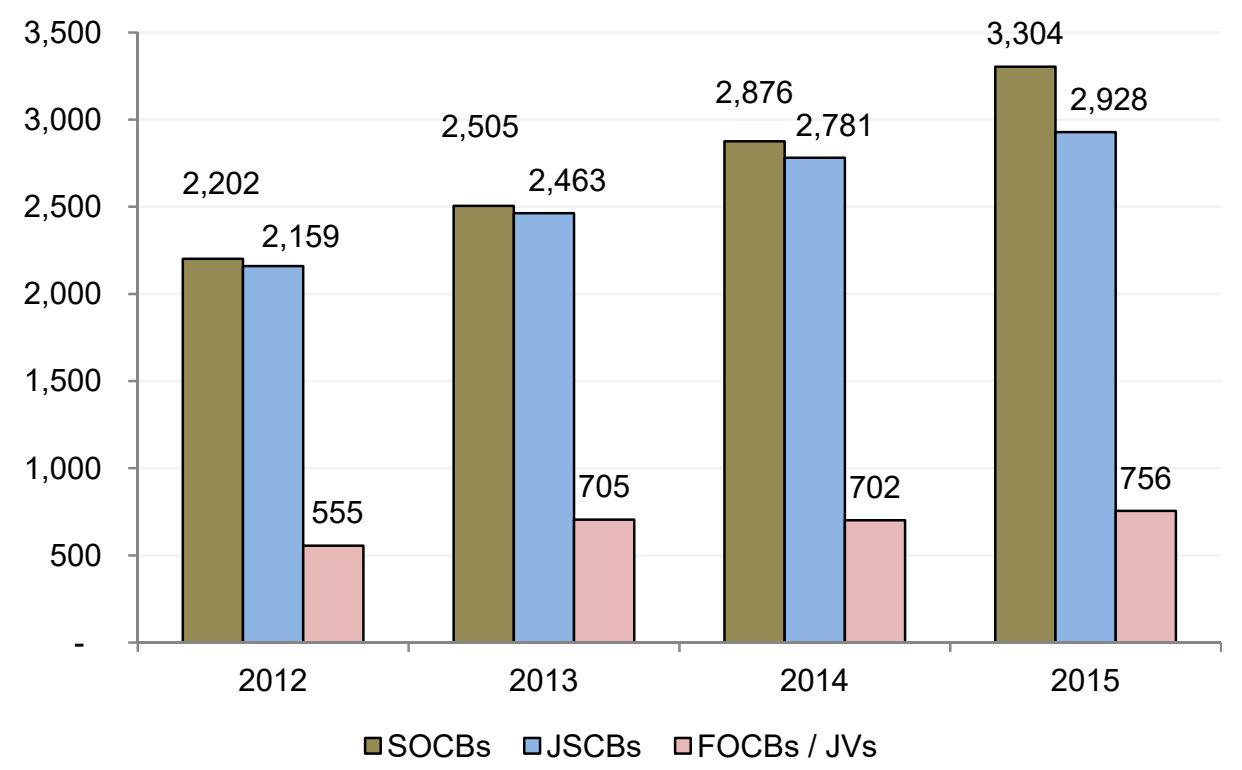

From Fig. 8, although total assets of SOCBs have declined over the past years, they are still holding the largest assets in the system, outweighing the foreign banks. However, JSCBs collectively have become stronger, and on par with SOCBs.

Figure 9. Assets by ownership

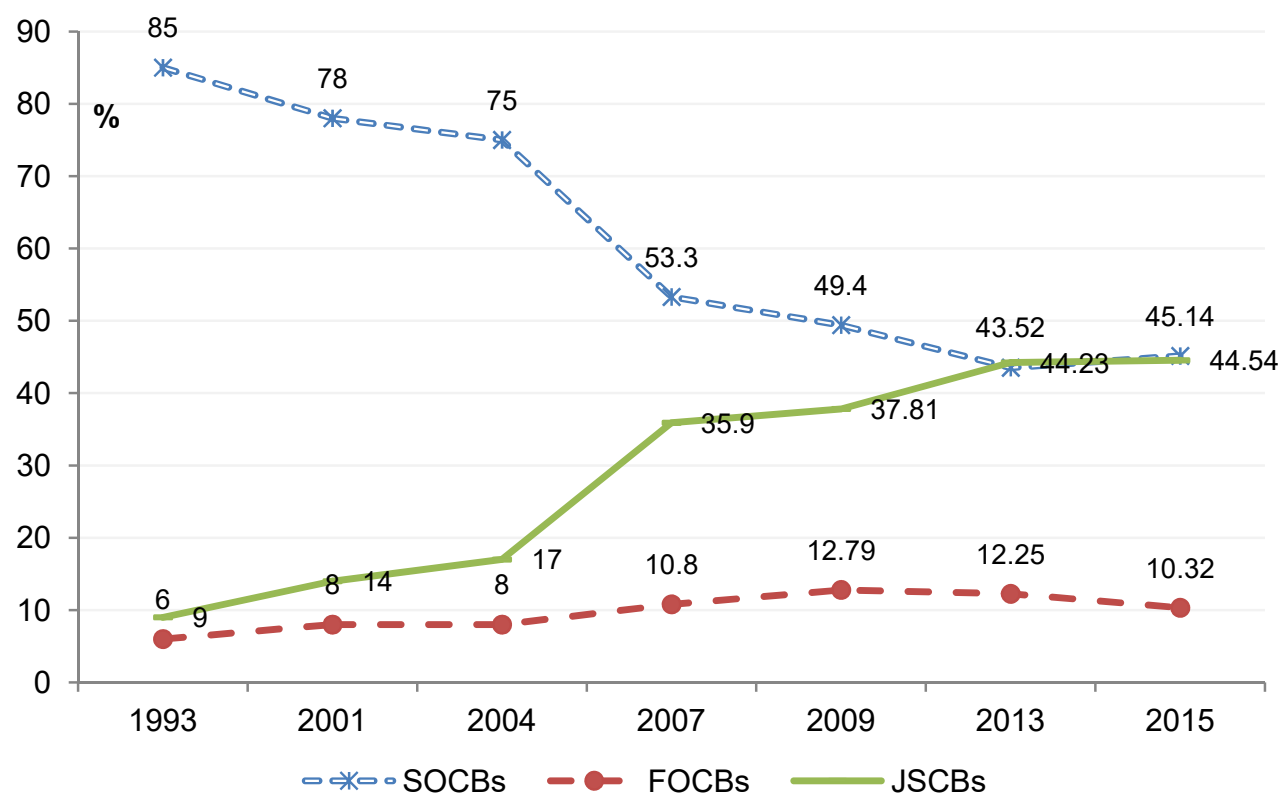

Source: Author's compilation. 
There are special entities in the banking sector, established to serve the development and poverty reduction programs: Vietnam Bank for Social Policy (VBSP), Vietnam Development Bank (VDB), and Cooperative Bank of Vietnam (CoopBank).

VBSP was established following Decree 131/2002/QD-TTg (Oct 4, 2002) by restructuring the then Bank for the Poor, with initial equity of VND 5,000 billion. In early 2016, this bank had a total capital of US\$486 million and total assets of US\$6.56 billion. VDB was founded on May 19, 2006 (PM's decision 108/2006/QDTTg), initially with a chartered capital of VND 5,000 billion. Its total assets in 2013 were US $\$ 14.2$ billion. CoopBank was the result of the transforming of the Central People's Credit Fund based on license 166/GP-NHNN (Jun 4, 2013), having a statutory capital of VND 3,000 billion. As of Jan 2016, CoopBank had total equity of US\$162 million and total assets of US\$1,020 million.

Domestic commercial banks have been able to increase their equity base thanks to public offerings on the Vietnam Stock Market (VSM). Since 2005, banks have collectively raised the additional equity amount of US $\$ 13$ billion. In 2015 the capital adequacy ratios were $9.4 \%$ at SOCBs, $12.7 \%$ JSCBs and $33.8 \%$ FOCBs.

Banks' profitability and investment efficiency have generally been considered modest, and showed some sign of decline in recent years, with ROEs in 2014 for SOCBs standing at $6.92 \%$, JSCBs $4.64 \%$ and FOCBs $3.79 \%$; and ROA: SOCBs $0.53 \%$, JSCBs $0.40 \%$ and FOCBs $0.61 \%$.

The development of the banking sector is correlated with the expansion of credit supply to the economy. The credit-to-GDP ratio was $71 \%$ in 2006 , and $116 \%$ in 2010 . On average, annual credit growth was $33 \%$ in the $2006-2010$ period. In this period, both FDI and FPI inflows surged abruptly, adding a large amount of money to the economy. In 2007 alone, US\$17.7 billion flowed in, leading to the central bank's net forex purchase of US $\$ 10.2$ billion. Without being sterilized properly, M2 surged by $46 \%$ in the year, creating a tremendous inflation pressure. The credit growth rate slowed down to $18 \%$ in 2015 while both M2 and bank deposits expanded by around 14\% in the same year.

Figure 10. Credit growth (\%/year) 


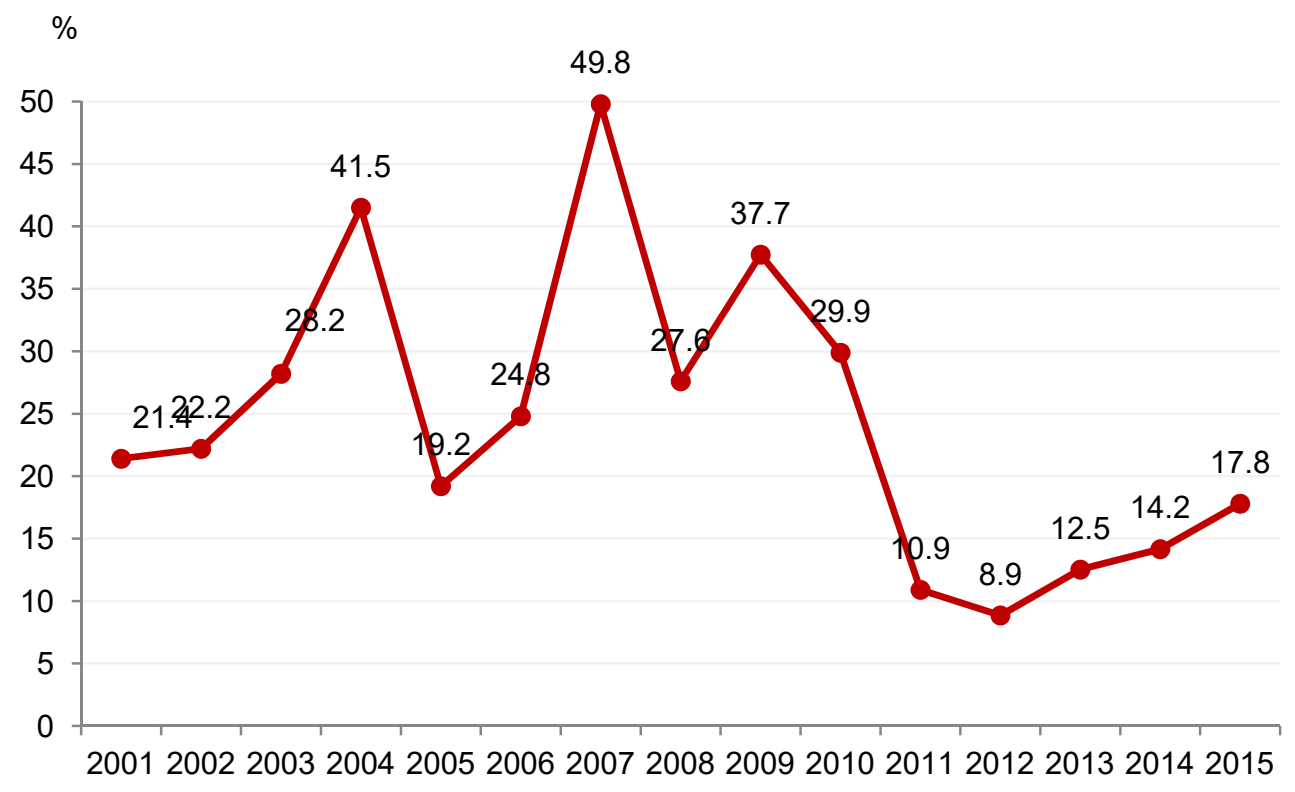

Source: SBV.

Banks also earn their incomes from forex operations. Fluctuations and increasing transaction volumes have created a lucrative market for commercial banks. Vietnamese individuals are allowed to keep foreign currency deposits (FCD), mostly USD, in their bank accounts and saving books. A higher FCD/M2 ratio reflects the 'dollarization' issue. This indicator for VFS varied from 5\% during 1992-1996, to 19\% (2000-2001), 15\% (20082009), 20\% (2010), and to 15\% (2011-2015).

Figure 11. US\$:VND exchange rate, 2003-2016

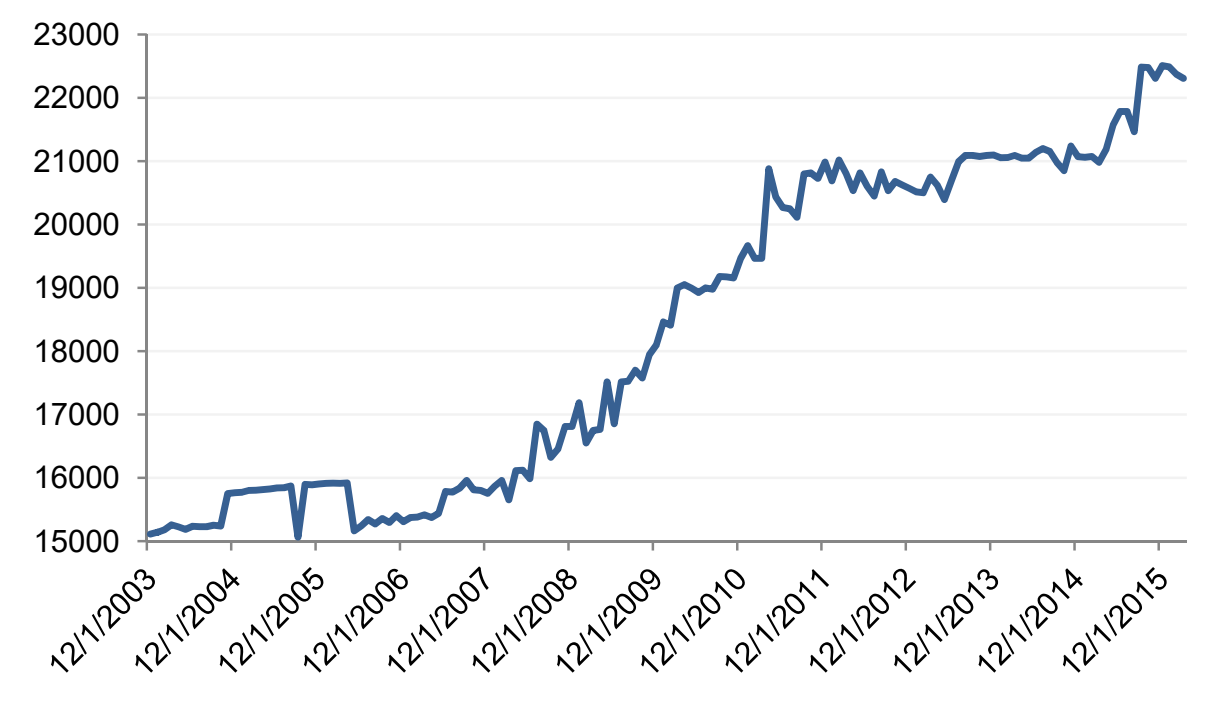

Source: OTC-Interbank 
Banks' forex revenues come from various trades: spot, swaps, futures, and options. No aggregates are available, but some typical examples can illustrate the market size in 2011. Eximbank had total values of currency swaps for its clients worth US\$195 million, and other FIs US $\$ 5.78$ billion. ACB Bank also held a total value of gold futures call options worth US $\$ 1.78$ billion and sold put contracts totaling US $\$ 1.73$ billion.

In addition, to diversify sources of income, banks have expanded retail banking services to reach out to individuals with more bank cards, ATMs and POS. Domestic debit cards and ATMs appeared first in 1993, and international credit cards in 1996. But ATM and POS became popular only in 2003 when the number of bank cards nationwide reached 234,000 . Electronic banking activities have since flourished, with 31.7 million cards in 2010, and 88.21 million in 2015.

Table 6. Bank cards, ATM and POS

\begin{tabular}{|l|r|r|r|r|r|r|r|r|}
\hline Year & \multicolumn{1}{c|}{ Debit } & \multicolumn{1}{c|}{ Credit } & \multicolumn{1}{c|}{ Prepaid } & \multicolumn{1}{c|}{ Domestic } & \multicolumn{1}{c|}{ Int'l. } & \multicolumn{1}{c|}{ Total } & \multicolumn{1}{l|}{ ATM } & \multicolumn{1}{c|}{ POS } \\
\hline 2010 & 30.12 & 0.44 & 1.14 & 30.115 & 1.585 & 31.70 & 11,700 & 54,000 \\
\hline 2011 & 39.48 & 1.05 & 1.47 & 39.48 & 2.52 & 42.00 & 13,600 & 77,500 \\
\hline 2012 & 50.89 & 1.62 & 1.78 & 50.26 & 4.03 & 54.29 & 14,500 & 104,900 \\
\hline 2013 & 61.11 & 2.43 & 2.67 & 59.87 & 6.34 & 66.21 & 15,400 & 132,000 \\
\hline 2014 & 73.59 & 3.29 & 3.51 & 71.61 & 8.78 & 80.39 & 16,018 & 172,360 \\
\hline 2015 & - & - & - & - & - & 88.21 & 16,112 & 192,255 \\
\hline
\end{tabular}

Bank cards are now shifting to integrated-circuit card technology. Cards can help with payments for numerous types of bill (electricity, water, cable TV, phone, and online transactions). Quality and security of electronic banking have improved significantly since 2011. The above fact shows a tremendous development if one looks to the fact that by 2011, only $15 \%$ of adults had access to a debit card (Kalra 2015).

\section{Vietnam Stock Market (VSM):}

VSM consists of two stock exchanges: HOSE (starting in July 2000) and HNX (starting July 2005). Fig. 12 shows the evolution of two widely cited market indexes during 20052015 (VNIndex/HNXIndex-above), and average Price/Earning ratios (P/E-below) for HOSE/HNX.

Figure 12. VNIndex (HOSE) and HNXIndex 

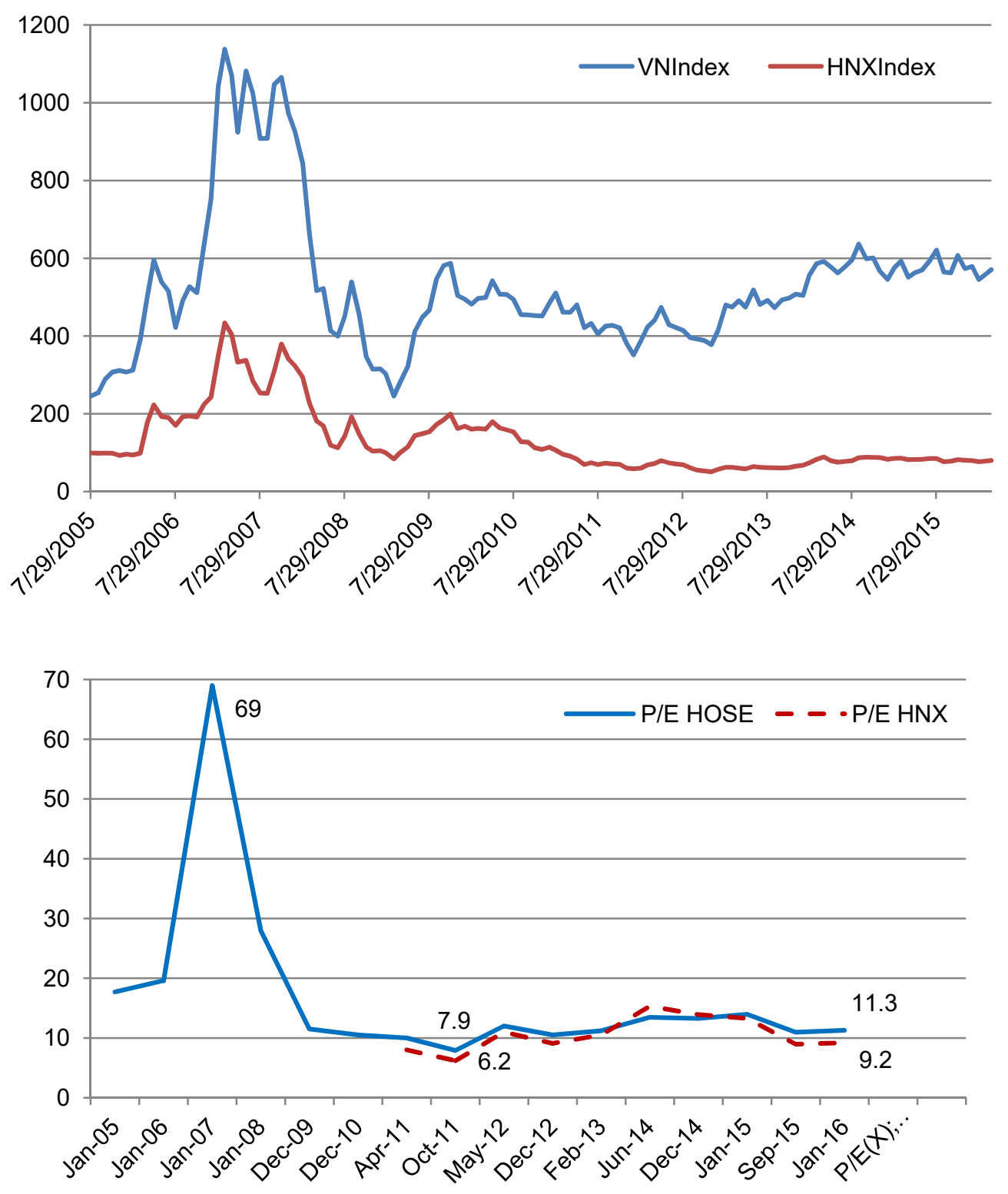

As of March 2016, VSM has 312 joint-stock companies listed on HOSE and 388 on HNX; with a total market capitalization of nearly $33 \%$ of GDP.

Table 7. Listed firms on VSM

\begin{tabular}{|c|c|c|c|}
\hline Year & $\begin{array}{l}\text { Newly listed } \\
\text { firms }\end{array}$ & $\begin{array}{l}\text { Newly listed shares } \\
\text { (million) }\end{array}$ & $\begin{array}{l}\text { Market values of new } \\
\text { shares (billion VND) }\end{array}$ \\
\hline 2000 & 5 & 47.11 & 11,359 \\
\hline 2001 & 4 & 13.95 & 1,341 \\
\hline 2002 & 10 & 53.93 & 6,672 \\
\hline 2003 & 2 & 4.98 & 161 \\
\hline 2004 & 26 & 5.20 & 626 \\
\hline
\end{tabular}




\begin{tabular}{|r|r|r|r|}
\hline 2005 & 9 & 187.16 & 12,142 \\
\hline 2006 & 138 & $1,971.91$ & 325,687 \\
\hline 2007 & 52 & $1,489.99$ & 173,036 \\
\hline 2008 & 81 & $1,016.14$ & 48,486 \\
\hline 2009 & 132 & $4,237.41$ & 354,247 \\
\hline 2010 & 233 & $3,996.70$ & 86,077 \\
\hline 2011 & 83 & $2,289.34$ & 68,695 \\
\hline 2012 & 30 & $2,236.46$ & 100,044 \\
\hline 2013 & 17 & 308.68 & 7,313 \\
\hline 2014 & 45 & $3,822.42$ & 92,455 \\
\hline 2015 & 112 & $4,604.76$ & 75,824 \\
\hline $2016\left(^{*}\right)$ & 19 & 989.27 & 8,148 \\
\hline \multicolumn{2}{|r|}{ Source: Author's compilation. ( $^{*}$ As of March $20,2016}$. \\
\hline
\end{tabular}

Both size and liquidity have grown over time. If in 2005, the average daily trade was $<700,000$ shares, the figure increased to 2.6 million in 2006, and 18 million in 2008. In 2014, VSM saw the largest trade volume of 47.4 billion shares, worth about US $\$ 35$ billion. In 2016Q1, the average daily value was around US\$100 million.

Table 8. Liquidity on VSM, 2011-2015

\begin{tabular}{|c|r|r|r|r|}
\hline \multirow{2}{*}{ Year } & \multicolumn{2}{|c|}{$\begin{array}{c}\text { Trade volume (billion } \\
\text { shares) }\end{array}$} & \multicolumn{1}{c|}{ Trade values (billion VND) } \\
\cline { 2 - 5 } & HOSE & \multicolumn{1}{c|}{ HNX } & HOSE & \multicolumn{1}{c|}{ HNX } \\
\hline 2011 & 18.88 & 7.94 & - & - \\
\hline 2012 & - & 12.14 & 216,881 & 82,081 \\
\hline 2013 & 16 & 10.57 & 260,985 & 199,527 \\
\hline 2014 & 30.45 & 16.98 & 533,052 & 135,035 \\
\hline 2015 & 28.13 & 11.54 & 482,046 & \\
\hline
\end{tabular}

As seen in Fig. 13, market size increased fast during 2006-2015, with 2015 year-end market capitalization standing at $33 \%$ of GDP.

Figure 13. VSM market capitalization (\%GDP) 


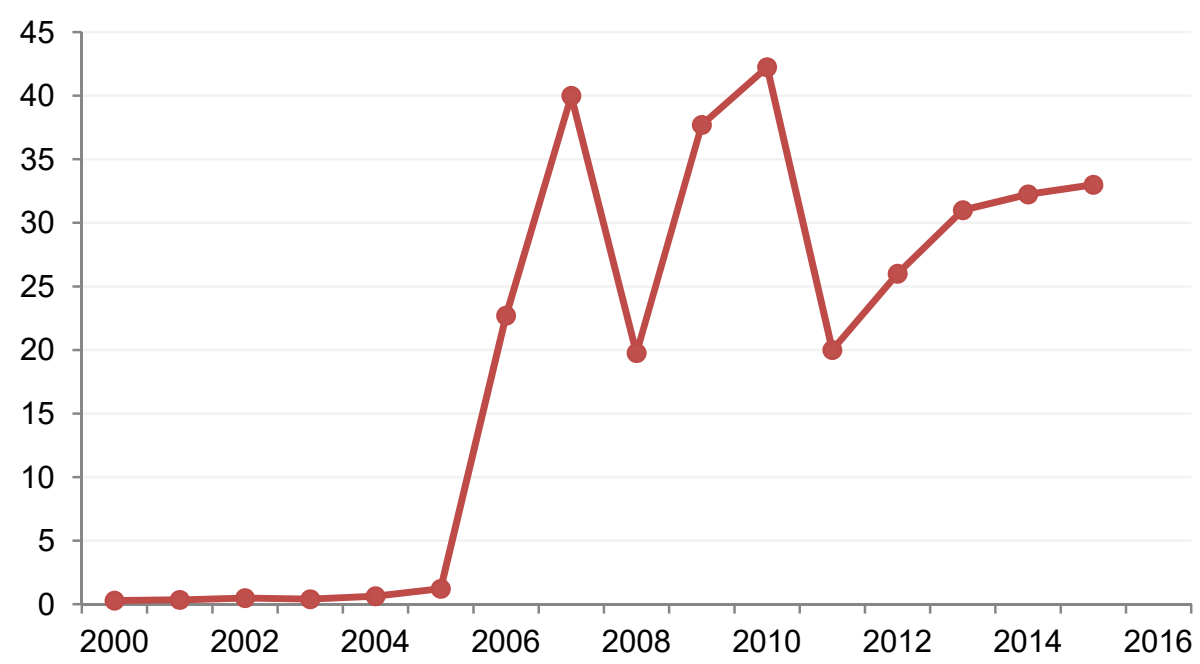

Source: Author's compilation from SSC/HOSE/HNX reports.

Two nosedives of stock prices seen in 2008 and 2011 occurred when inflation rates were $19.89 \%$ and $18.13 \%$, respectively. The worst year in VSM 17-year history was 2011 when HOSE's value decreased by $25 \%$ from that of 2010; HNX lost 36\%. Index returns on HOSE/HNX based on VNIndex/HNXIndex are provided in Fig. 14, where market volatility changes over time.

Figure 14. Monthly index returns on VSM (HOSE/HNX)

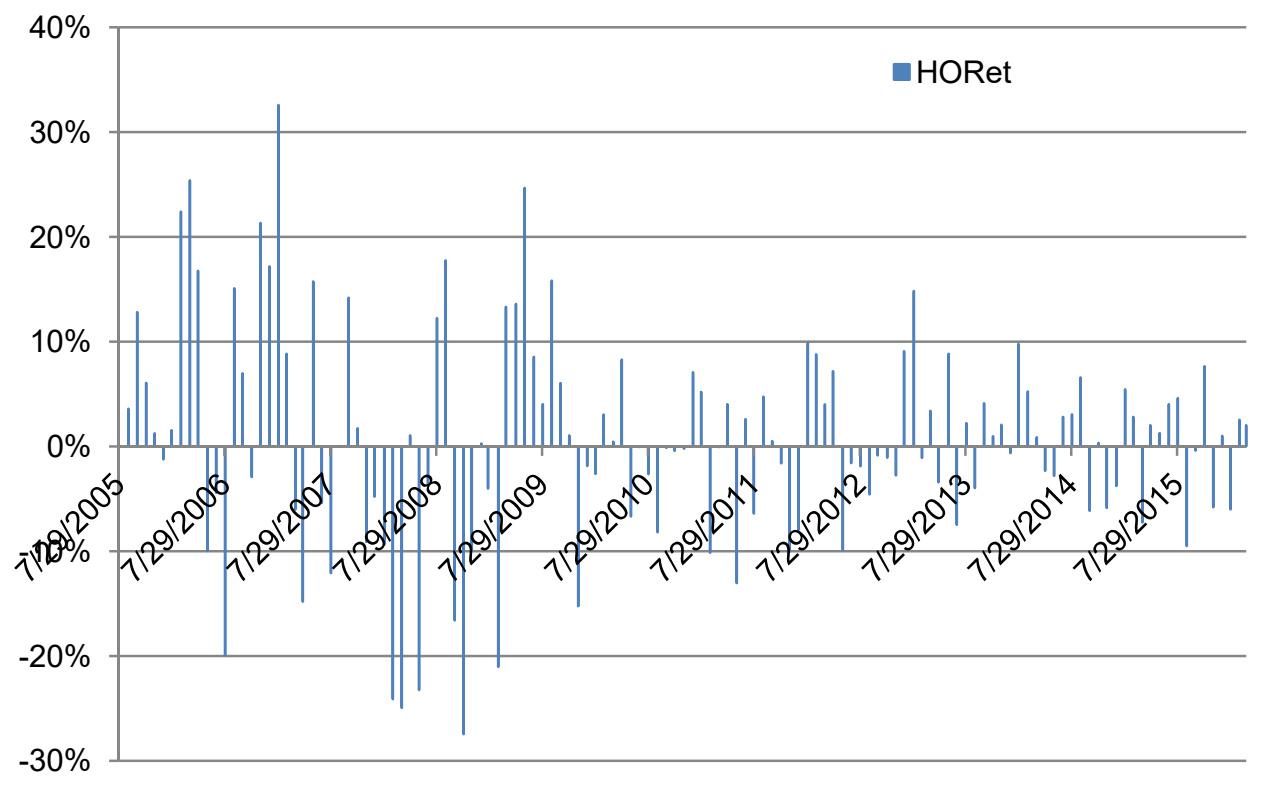




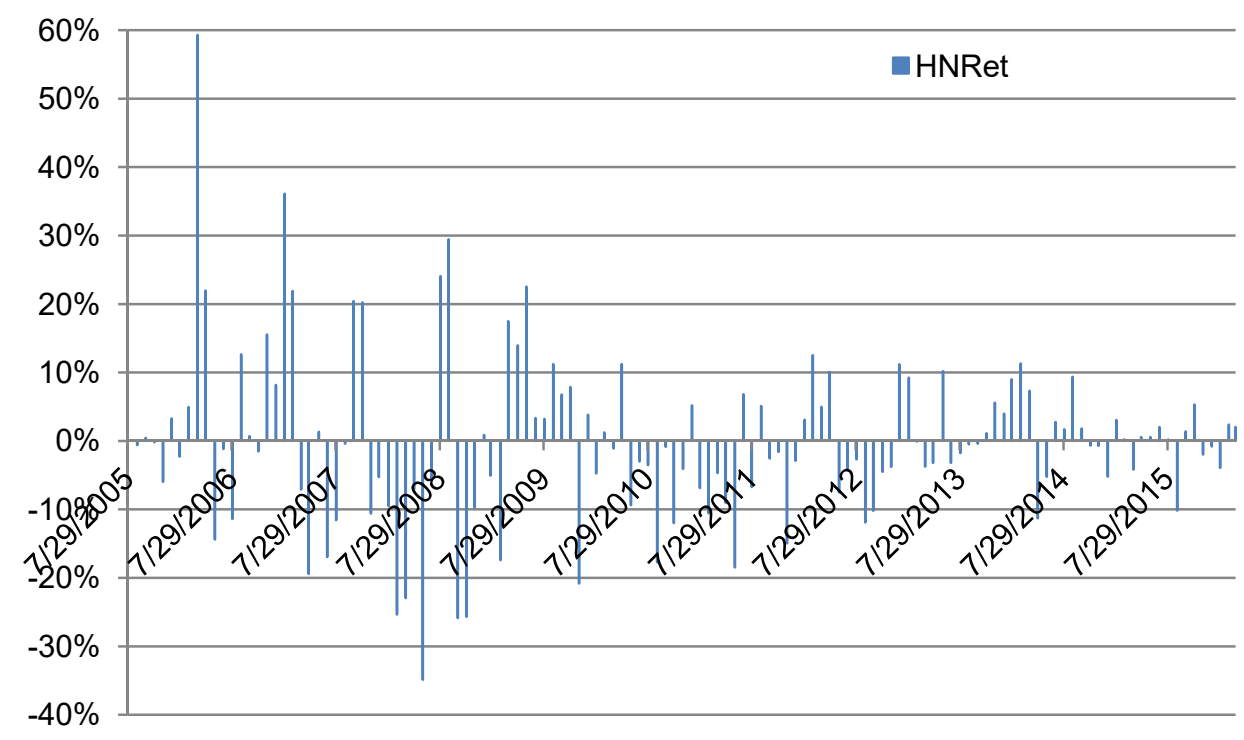

VSM can now perform better in both IPOs and seasoned offerings. Firms have issued shares worth approximately US $\$ 100$ billion in VSM's first 17-years. During the 2010-2015 period, US\$53 billion was raised, of which in 2015 the total value of funds raised reached US $\$ 13.2$ billion, or about $28 \%$ of Vietnam's total capital expenditures. In addition, VSM helped to attract about US $\$ 15$ billion FPI.

Securities broker firms:

The number of securities companies grew with VSM's size, as shown in Fig. 15.

Figure 15. Number of securities firms, 2000-2015

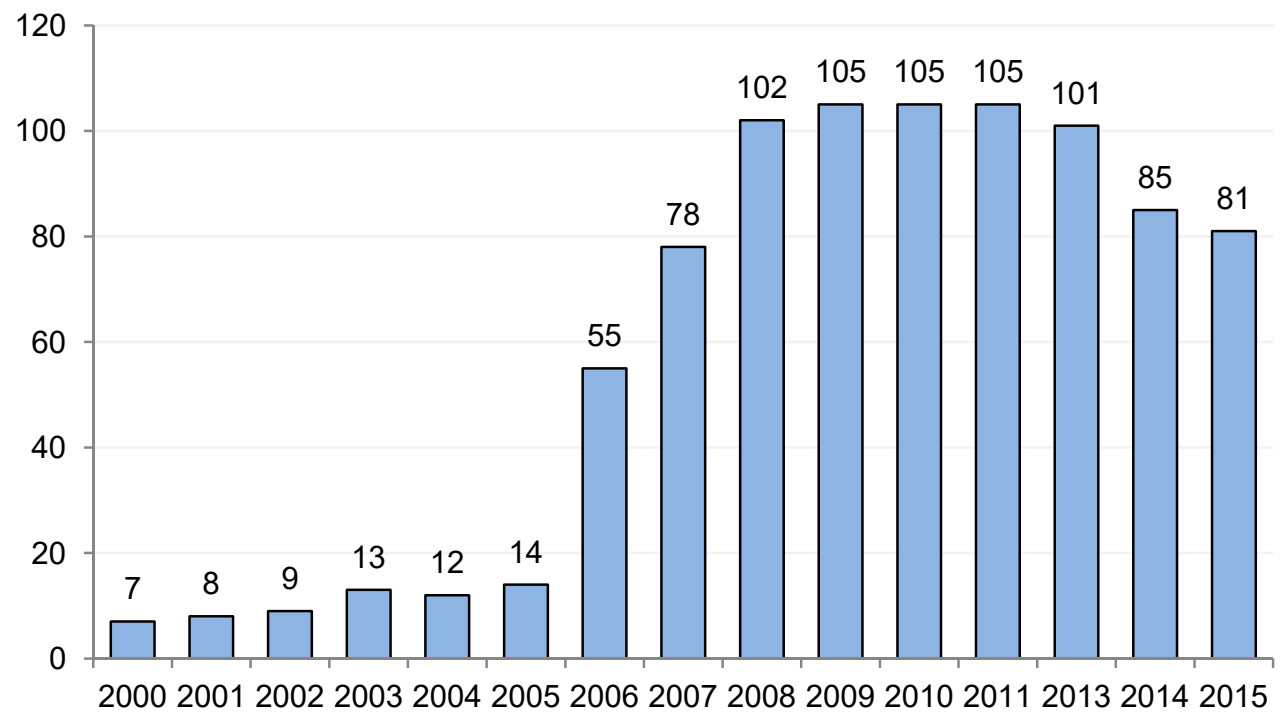

Soure: SSC. 
Dozens of securities broker firm have made their fortune on VSM, especially those with strong equity (Table 10) and dominating market shares (Table 9).

Table 9. Top 10 broker firms by market share in 2015

\begin{tabular}{|l|r|l|r|}
\hline \multicolumn{2}{|c|}{ HNX } & \multicolumn{2}{c|}{ HOSE } \\
\hline Company & Share (\%) & Company & Share (\%) \\
\hline Saigon Securities & 11.27 & Saigon Securities & 12.92 \\
\hline VNDIRECT & 9.94 & Ho Chi Minh City Securities & 12.45 \\
\hline Saigon-Hanoi Securities & 8.34 & VietCapital Securities & 9.91 \\
\hline KIS Vietnam & 6.36 & VNDIRECT & 5.64 \\
\hline MB Securities & 5.19 & MB Securities & 5.35 \\
\hline VietCapital Securities & 4.82 & Saigon-Hanoi Securities & 5.00 \\
\hline HCMC Securities & 4.61 & ACB Securities & 4.28 \\
\hline Maritime Securities & 4.41 & KIS Vietnam & 4.21 \\
\hline ACB Securities & 3.81 & BIDV Securities & 4.11 \\
\hline FPT Securities & 3.54 & FPT Securities & 2.90 \\
\hline
\end{tabular}

About 800,000 stock trading accounts were registered with the Vietnam Securities Depository Center (VSD) in 2009, a substantial increase from 530,000 in 2008. But in March 2016, VSD already counted 1.48 million trading accounts.

Table 10. Securities firms with the largest chartered capital by 2015

\begin{tabular}{|l|r|}
\hline Firms & $\begin{array}{c}\text { Capital } \\
\text { (billion VND) }\end{array}$ \\
\hline Saigon Securities & 3,538 \\
\hline Agribank Securities & 2,120 \\
\hline Kim Long Securities & 2,025 \\
\hline VNDirect Securities & 1,550 \\
\hline ACB Securities & 1,500 \\
\hline HCMC Securities & 1,273 \\
\hline MB Securities & 1,221 \\
\hline KIS Vietnam & 1,112 \\
\hline Techcombank Securities & 1,000 \\
\hline Saigon-Hanoi Securities & 1,000 \\
\hline
\end{tabular}

Source: SSC/HNX/HOSE.

High inflation and restrictive monetary policy caused brokerage firms to make a substantial loss in 2011. In 2014, surviving firms were able to improve their performance, and their collective profits jumped to US\$150 million. The sector's ROA and ROE were $5.15 \%$ and $8.58 \%$, respectively in 2014, twice of those of 2010 .

Figure 16. Net-Profit-After-Taxes (NPAT) of securities firms 


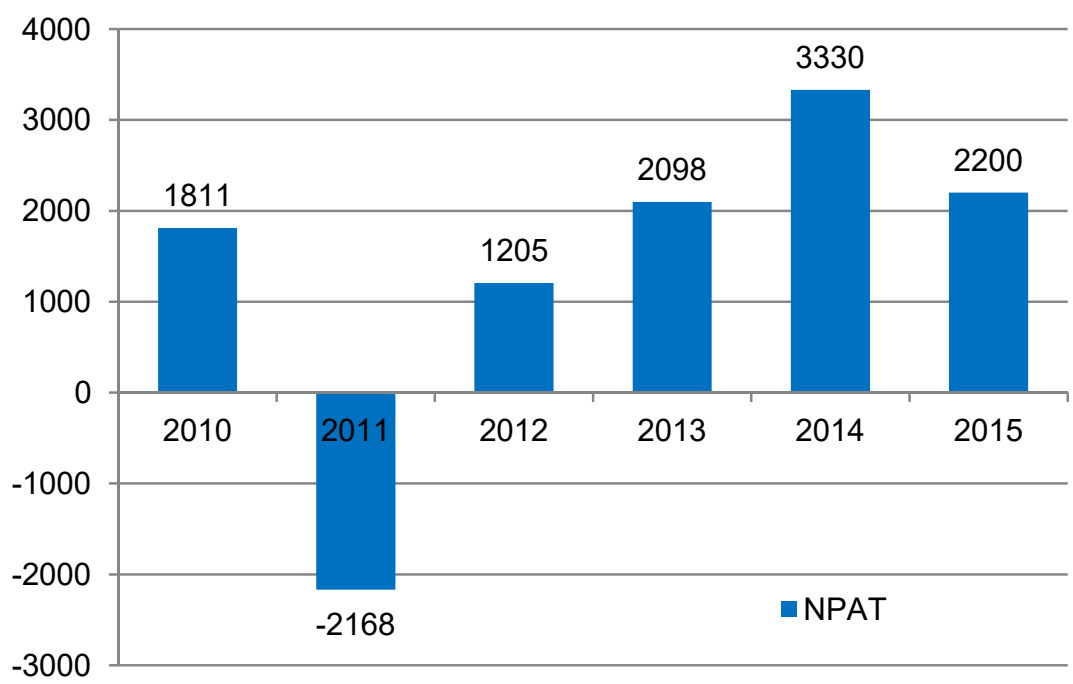

Source: SSC; unit: billion VND.

By the end of 2015, only 81 survived the fierce competition who collectively held total assets of US\$3,395.5 million and total equity of US\$1,891 million. Among them, 20 largest made total revenues of US\$345.5 million, and profits of US\$131.8 million.

\section{Insurers/Insurance markets:}

Before Doi Moi, the insurance business had been monopolized by Bao Viet Insurance, an SOE established on 17/12/1964 offering two dozens of basic insurance needs. The reform came with Decree 100/CP (18/12/1993), which allowed private and foreign investors to participate in the business. The scope of activities also expanded, covering a wide range of previously inexistent activities.

The market boomed in 1995 when dozens of insurance firms and JVs were licensed. Additionally, 40 foreign insurers' representative offices and nearly 70,000 insurance agents were approved. Nowadays, 61 insurance and related service firms are fully operational in Vietnam, offering 800 different products meeting almost every consumer's need.

Table 11. Number of insurance and service broker businesses in Vietnam

\begin{tabular}{|lrrrrrrr|}
\hline & 2007 & 2008 & 2009 & 2010 & 2011 & 2013 & 2015 \\
\hline Nonlife insurance & 22 & 27 & 28 & 29 & 29 & 29 & 29 \\
Life insurance & 9 & 11 & 11 & 12 & 14 & 16 & 17 \\
Reinsurance & 1 & 1 & 1 & 1 & 2 & 2 & 2 \\
Service broker firms & 8 & 10 & 10 & 11 & 12 & 12 & 12 \\
Branch of foreign nonlife & 0 & 0 & 0 & 0 & 0 & 0 & 1 \\
\hline Total & 40 & 49 & 50 & 53 & 57 & 59 & 61 \\
\hline
\end{tabular}

It is also noteworthy that six life insurance businesses have been offering pension products—namely Manulife, AIA, Daiichi, PVI Sun Life, Bao Viet Life, and Prudential.

Figure 17. Life insurance market share in 2015 


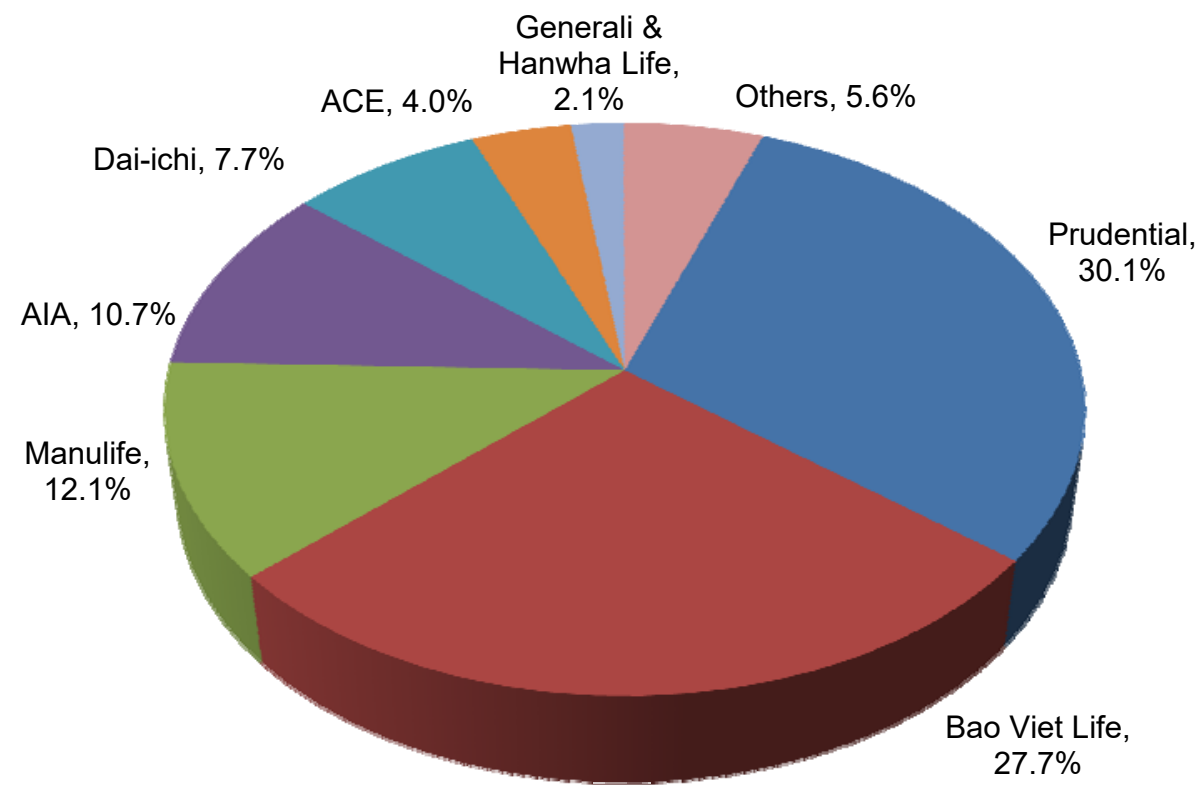

Source: Department of Insurance Market Administrion

Conventional nonlife insurance needs are mainly served by domestic firms-as shown in Fig. 18-with PetroVietnam Insurance (PVI) occupying the largest share due to the surge of risky oil exploring/mining activities during 1995-2015.

Figure 18. Nonlife insurance market share in 2015

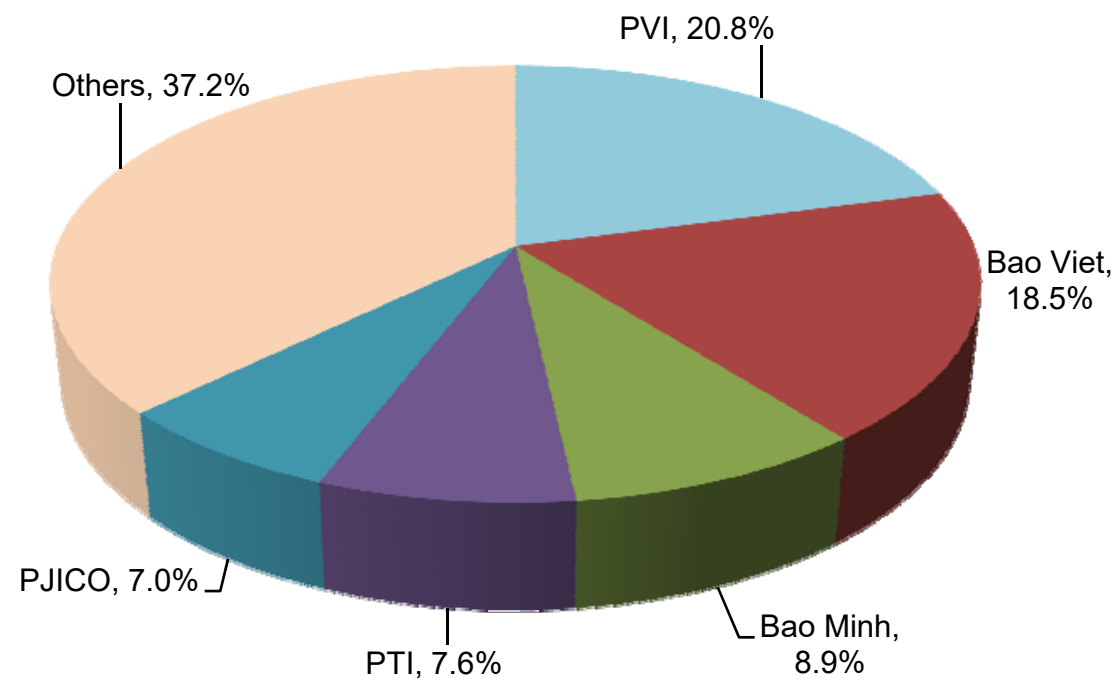

Source: Department of Insurance Market Administrion

In 2015 , total insurance revenues were estimated at approximately US $\$ 3.13$ billion, representing an annual growth of $21.43 \%$, of which nonlife revenues reached US $\$ 1.46$ 
billion, and life-insurance revenues US $\$ 1.67$ billion. Revenue growth for life insurance was at $29.5 \%$, outpacing nonlife, $14 \%$. Insurers also honored total financial obligations worth about US\$955 million.

Figure 19. Financial aggregates of the insurance industry

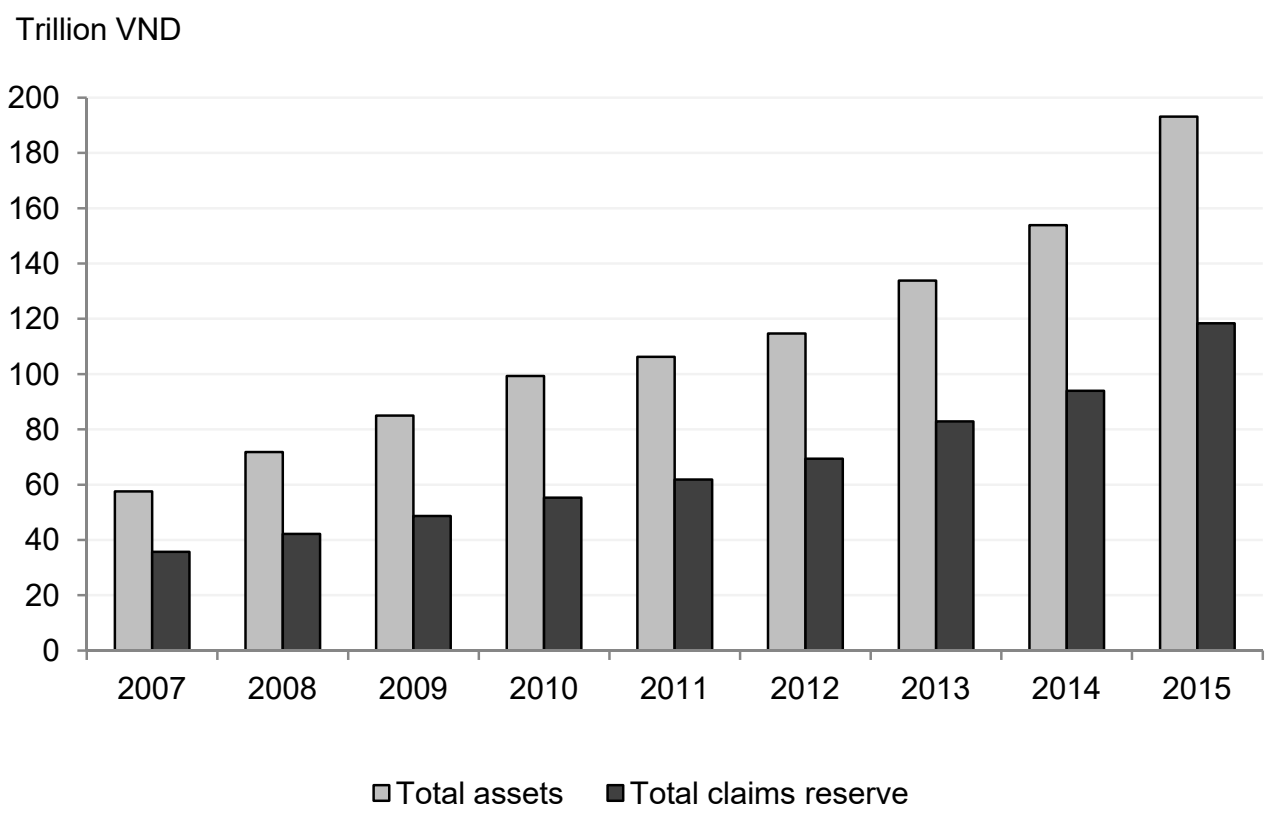

Source: Department of Insurance Market Administration; unit: trillion VND.

Total assets of the insurance sector stood at US\$8.78 billion in 2015, increasing by $12.68 \%$ from 2014 , of which, nonlife subsector accounted for $31.8 \%$, and life $68.2 \%$.

Table 12. Industry's revenues breakdown

\begin{tabular}{|l|r|r|r|r|}
\hline & \multicolumn{1}{|c|}{2007} & 2010 & 2013 & \multicolumn{1}{c|}{2015} \\
\hline Insurance revenues & 17,650 & 30,842 & 47,626 & 68,688 \\
\hline - Nonlife & 8,213 & 17,070 & 24,359 & 32,038 \\
\hline - Life & 9,437 & 13,772 & 23,267 & 36,650 \\
\hline $\begin{array}{l}\text { Investment } \\
\text { revenues }\end{array}$ & 6,623 & 8,296 & 10,147 & 13,000 \\
\hline Total & 24,273 & 39,138 & 57,773 & 81,374 \\
\hline
\end{tabular}

Total revenues of 12 insurance brokerage firms also reached US\$26.8 million in 2015, increasing by $14.3 \%$ from 2014.

Figure 20. Investments by insurance companies 


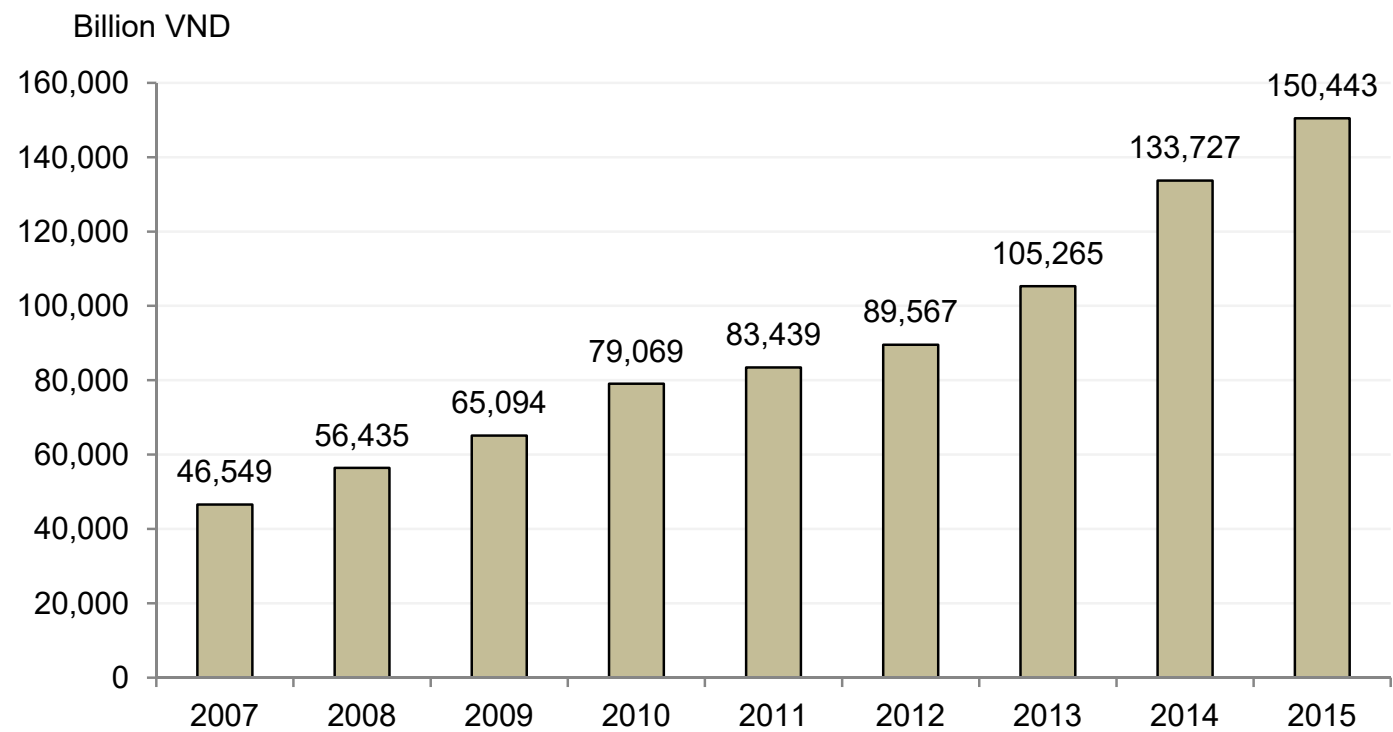

Source: Department of Insurance Market Administrion.

Insurance companies made investments into the economy, with 2015 total stock standing at US $\$ 6,383$ million, $79.2 \%$ of which came from life insurers. Insurers have recently been the main buyers of government bonds, increasingly bonds with long maturities. In 2015 , they bought 20 -year government bonds worth US $\$ 283$ million; a group of major insurers even proposed the government to issue 30-year bonds.

With over 200,000 registered agents, life insurance firms have been able to sell new policies during 2013-2015: 1,178,390; 1,252,157; 1,298,776. Industry experts expect life insurance market will continue to expand by $25 \%$ in 2016 , and nonlife insurance $18 \%$. The number of agents increased during 2005-2015 from 35,000 to almost 70,000.

\section{Financial companies:}

First financial companies were licensed in 1997 to provide consumer finance and serve domestic trades. Their collective balance sheets showed an increase in shareholders' equity from US $\$ 520.8$ million in 2012 to US $\$ 815.6$ million in 2015 , and total assets decreased from US $\$ 7.49$ billion to US $\$ 4.04$ billion.

Table 13. Financial companies

\begin{tabular}{|c|c|c|c|}
\hline Firm & Location & License / date & $\begin{array}{c}\text { Capital } \\
\text { (billion VND) } \\
\end{array}$ \\
\hline Post\&Telecom Finance Co. Ltd. (PTI) & \multirow{7}{*}{ Hanoi } & 03/GP-NHNN; 10/10/1998 & 500 \\
\hline $\begin{array}{l}\text { Maritime Bank Finance Co. Ltd. (formerly: } \\
\text { Vinatex Finance Co.) }\end{array}$ & & 255/GP-NHNN; 16/11/2010 & 500 \\
\hline EVN Finance Joint-Stock Co. & & 187/GP-NHNN; 7/7/2008 & 2.500 \\
\hline Handico Finance Joint-Stock Co. & & 157/GP-NHNN; 6/6/2008 & 550 \\
\hline $\begin{array}{l}\text { Vietnam Techcom Finance Joint-Stock Co. } \\
\text { (formerly: Chemical Finance Co.) }\end{array}$ & & 340/GP-NHNN; 29/12/2008 & 600 \\
\hline Song Da Finance Joint-Stock Co. & & 137/GP-NHNN; 23/5/2008 & 686 \\
\hline Vietnam Shipbuilding Finance Co. Ltd. & & 04/GP-NHNN; $16 / 3 / 2000$ & 2.523 \\
\hline
\end{tabular}




\begin{tabular}{|c|c|c|c|}
\hline Vinaconex-Viettel Finance Joint-Stock Co. & & 304/GP-NHNN; 14/11/2008 & 1.000 \\
\hline Cement Finance Joint-Stock Co. & & 142/GP-NHNN; 29/5/2008 & 605 \\
\hline $\begin{array}{l}\text { Mirae Asset Finance Co. (Vietnam) Ltd. (100\% } \\
\text { FOC) }\end{array}$ & \multirow{7}{*}{$\mathrm{HCMC}$} & 250/GP-NHNN; 11/11/2010 & 500 \\
\hline $\begin{array}{l}\text { VPBank Finance Co. Ltd. (formerly: TKV CMF } \\
\text { Co.) }\end{array}$ & & 02/GP-NHNN; 30/1/2007 & 1.500 \\
\hline HD-Saison Finance Co. & & 05/GP-NHNN; 8/5/2007 & 550 \\
\hline $\begin{array}{l}\text { HomeCredit Vietnam Finance Co. Ltd. } \\
\text { (100\% FOC; formerly: PPF Finance Vietnam) }\end{array}$ & & 112/GP-NHNN; 18/4/2008 & 550 \\
\hline Prudential Vietnam Finance Co. (100\% FOC) & & 10/GP-NHNN; 10/10/2006 & 616 \\
\hline IACCS International Vietnam Finance Co. Ltd. & & 90/GP-NHNN; $13 / 4 / 2010$ & 550 \\
\hline $\begin{array}{l}\text { Toyota Financial Services Vietnam Co. Ltd. } \\
(100 \% \text { FOC })\end{array}$ & & 208/GP-NHNN; 24/7/2008 & 500 \\
\hline
\end{tabular}

As non-deposit-taking firms, they are focused on nonbank services, especially riskier consumer goods financing. In the 2014-2016 period, they financed about $20 \%$ of consumer goods purchases nationwide, with interest margins typically running from $25-30 \%$ p.a., twice of the normal bank rates. Several pioneers are now exploring personal wealth management services in the context of increasing risks due to higher unpredictability of profits of financial assets such as gold, forex or equity stocks, whereas the number of Vietnamese super-rich is expected to grow fast over the next ten years.

\section{Financial leasing:}

Six first financial lessors appeared in the mid-1990s, providing small-scaled termfinance alternatives to private SMEs, who then suffered from discriminatory lending by SOCBs. Banks also established their wholly-owned financial leasing subsidiaries, as lessors could be more flexible regarding decision-making. From 2000, the government raised the bar for new entrants, requiring an equity minimum of US $\$ 5$ million. Lessors also entered a race in equity. Thus their equity base increased to US $\$ 70.5$ million in 2005 , and then US $\$ 136.4$ million in 2007, even though all lessors generated a mediocre NPAT of US $\$ 4.73$ million (ROE 3.5\%).

In the post-WTO period, lessors performed poorly, with profit margins declining over time. Flexible contract terms at times became dangerous as executives manipulated regulations and made financing decisions for personal profiteering, especially at SOCBfounded lessors such as the case of Vu Quoc Hao-former CEO of Agribank Leasing Co. 2who was sentenced to death in an embezzlement trial in 2014.

By 2016Q1, only Vietinbank Leasing, Vietcombank Leasing, BIDV Leasing, ACB Leasing, and Sacombank Leasing remain active while the rest drown in bad debts and losses.

\section{Investment companies/ETFs and equity products:}

When Vietnam - then called "the last frontier economy of Asia"—opened its door to the world in the early 1990s, pioneers, namely Templeton Vietnam Opportunity, Vietnam Fund, Vietnam Enterprise Investment Fund-VEIF, Vietnam Frontier Fund, Beta Mekong Fund, Beta Vietnam Fund, Lazard Vietnam, swiftly mobilized US\$700 million funds to make risky investments. But after the Asian financial crisis in 1997-98, only VEIF and Vietnam Frontier Fund remained in the country. The underdevelopment of domestical capital markets and lack of opportunities created a deadlock in investment industry until the birth 
of Vietnam stock market and acceleration of equitization programs, which sold off equity of SOEs (Painter 2005; Sjöholm 2006).

The new wave of investment funds in Vietnam started after the launch of the Vietnam Stock Market (VSM) in 2000. The FPI surge occurred in 2006-2007 after bullish reports HSBC and Merrill Lynch. Subsequently, 20 funds and 17 fund management firms were granted a business license by SSC (Table 14)—even Morgan Stanley managed to make its presence in Vietnam.

Table 14. Active investment funds in Vietnam

\begin{tabular}{|c|c|c|c|c|}
\hline Manager & Fund & Start & Equity & Remarks \\
\hline \multirow{2}{*}{ Dragon Capital } & Vietnam Growth Fund & 2004 & US\$190mn & $\begin{array}{l}\text { US\$283.85mn NAV } \\
24 / 3 / 2016 \text {. }\end{array}$ \\
\hline & $\begin{array}{l}\text { Vietnam Enterprise } \\
\text { Investment Ltd. }\end{array}$ & 1999 & - & $\begin{array}{l}\text { US } \$ 530.6 \mathrm{mn} \text { NAV } \\
24 / 3 / 2016 \text {. }\end{array}$ \\
\hline $\begin{array}{l}\text { Deutsche Asset } \\
\text { Management }\end{array}$ & DWS Vietnam Fund & 2006 & - & $\begin{array}{l}\text { US } \$ 323.82 \mathrm{mn} \text { NAV } \\
(29 / 2 / 2016) ; \text { Singapore } \\
\text { listed. }\end{array}$ \\
\hline $\begin{array}{l}\text { BIDV-Vietnam } \\
\text { Partners }\end{array}$ & BVIMVIF & 2007 & VND1500bn & \\
\hline \multirow{4}{*}{ IndochinaCapital } & Indochina Vietnam Fund & 1999 & - & Private/closed-ended funds \\
\hline & $\begin{array}{l}\text { Indochina Land Holdings- } \\
\text { ILH }\end{array}$ & 2005 & - & Private/closed-ended funds \\
\hline & ILH-2 & 2006 & US $\$ 265 \mathrm{mn}$ & Private/closed-ended funds \\
\hline & ILH-3 & 2010 & US\$180.3mn & Private/closed-ended funds \\
\hline \multirow{4}{*}{ Mekong Capital } & $\begin{array}{l}\text { Mekong Enterprise Fund- } \\
\text { MEF }\end{array}$ & 2002 & US\$18.5m & $\begin{array}{l}\text { 12-y life; divested from } 9 / 10 \\
\text { investments; the first growth } \\
\text { capital private equity fund. }\end{array}$ \\
\hline & MEF-II & 2006 & US\$50mn & $\begin{array}{l}\text { 12-y life; exited: } 7 / 10 \\
\text { investments in } \\
\text { retailing/distribution/FMCG. }\end{array}$ \\
\hline & MEF-III & 2015 & US\$87.4mn & $\begin{array}{l}\text { Target: US } \$ 150 \mathrm{mn} \text { equity. } \\
10 \text {-y; focus: } \\
\text { retail/restaurants/consumer } \\
\text { products/services. }\end{array}$ \\
\hline & Vietnam Azalea Fund & 2007 & US\$64mn & $\begin{array}{l}10 \text {-y life; exited from } 4 / 10 \\
\text { investments. }\end{array}$ \\
\hline \multirow{4}{*}{ VinaCapital } & Vietnam Opportunity Fund & 2003 & - & $\begin{array}{l}\text { Closed-end; London. } \\
\text { US } \$ 738.7 \mathrm{mn} \text { (NAV } \\
30 / 1 / 2015)\end{array}$ \\
\hline & VinaLand Fund & 2016 & US\$65mn & - \\
\hline & Vietnam Infrastructure Ltd & 2007 & - & $\begin{array}{l}\text { US\$209.2mn (NAV } \\
31 / 12 / 2015)\end{array}$ \\
\hline & DFJ VinaCapital LP & 2006 & US\$1.02bn & - \\
\hline $\begin{array}{l}\text { Vietnam Holding } \\
\text { Asset Mgt. }\end{array}$ & Vietnam Holding Limited & 2006 & US\$125mn & $\begin{array}{l}\text { Closed-end/London AIM; } \\
\text { NAV>US } \$ 215 \mathrm{mn} \\
(24 / 3 / 2016) .\end{array}$ \\
\hline $\begin{array}{l}\text { Deutsche Asset } \\
\text { Management }\end{array}$ & FTSE Vietnam UCITS-ETF & 2008 & - & $\begin{array}{l}\text { US } \$ 325.33 m n \text { NAV } \\
(23 / 3 / 2016) ; \text { London }\end{array}$ \\
\hline JPMorgan & $\begin{array}{l}\text { JPMorgan Vietnam } \\
\text { Opportunities Fund }\end{array}$ & 2006 & - & $\begin{array}{l}\text { US } \$ 138.3 m n \text { NAV } \\
(29 / 2 / 2016) ; \text { Hong Kong- } \\
\text { listed unit trust. }\end{array}$ \\
\hline Van Eck Global & $\begin{array}{l}\text { Market Vectors Vietnam- } \\
\text { ETF }\end{array}$ & 2009 & - & $\begin{array}{l}\text { US\$329.97mn NAV } \\
(24 / 3 / 2016) ; \text { NYSE/Arca }\end{array}$ \\
\hline
\end{tabular}




\begin{tabular}{|c|c|c|c|c|}
\hline BlackRock & $\begin{array}{l}\text { iShares MSCI Frontier } 100 \\
\text { Fund }\end{array}$ & 2012 & - & $\begin{array}{l}\text { US\$420.38mn NAV } \\
\text { (23/3/2016); VSM weight: } \\
\text { 3.52\%. NYSE/Arca }\end{array}$ \\
\hline $\begin{array}{l}\text { PXP Vietnam } \\
\text { Asset Mgt. }\end{array}$ & $\begin{array}{l}\text { PXP Vietnam Emerging } \\
\text { Equity Fund }\end{array}$ & 2005 & - & $\begin{array}{l}\text { US\$116.17mn NAV } \\
\text { (29/2/2016). Open- } \\
\text { ended/Berlin. }\end{array}$ \\
\hline \multirow{2}{*}{$\begin{array}{l}\text { Saigon Asset } \\
\text { Management }\end{array}$} & Vietnam Property Holding & 2007 & - & $\begin{array}{l}\text { US } \$ 16.87 \mathrm{mn} \text { NAV } \\
(30 / 3 / 2015) . \text { Open-ended. }\end{array}$ \\
\hline & Vietnam Equity Holding & 2007 & - & $\begin{array}{l}\text { US\$37.53mn NAV } \\
(11 / 3 / 2016) \text {. }\end{array}$ \\
\hline $\begin{array}{l}\text { Lion Global } \\
\text { Investors }\end{array}$ & LionGlobal Vietnam Fund & 2007 & - & $\begin{array}{l}\text { US\$123.75mn NAV } \\
\text { (29/1/2016). Open- } \\
\text { ended/unit trust. }\end{array}$ \\
\hline Artémis & Red River Holding & 2008 & - & $\begin{array}{l}\text { US } \$ 156 m \text { portfolio } \\
(1 / 3 / 2016) \text {. }\end{array}$ \\
\hline \multirow{3}{*}{ Jaccar } & Jaccar Capital Fund & 2006 & - & US\$26mn portfolio. \\
\hline & Vietnam Century Fund & 2009 & - & US\$36mn portfolio. \\
\hline & Jaccar Holdings & 2006 & - & US\$50mn portfolio. \\
\hline
\end{tabular}

As there exist different types of investment funds operating and holding equity assets in VSM, it is impossible to track all data on investments, portfolio values, and funds' performance. But the authorities-SSC and HOSE/HNX—can monitor local ETFs, such as VFMVN30.

\section{Bond markets:}

From 2005, VSM has also served as a major distribution system of government bonds, organizing public auctions. The government borrowed from public bonds investors approximately US $\$ 48$ billion in the 2010-2015 period, mostly 3- and 5-year terms (see Appendixes A2-A3).

Figure 21. Government bonds (outstanding) 


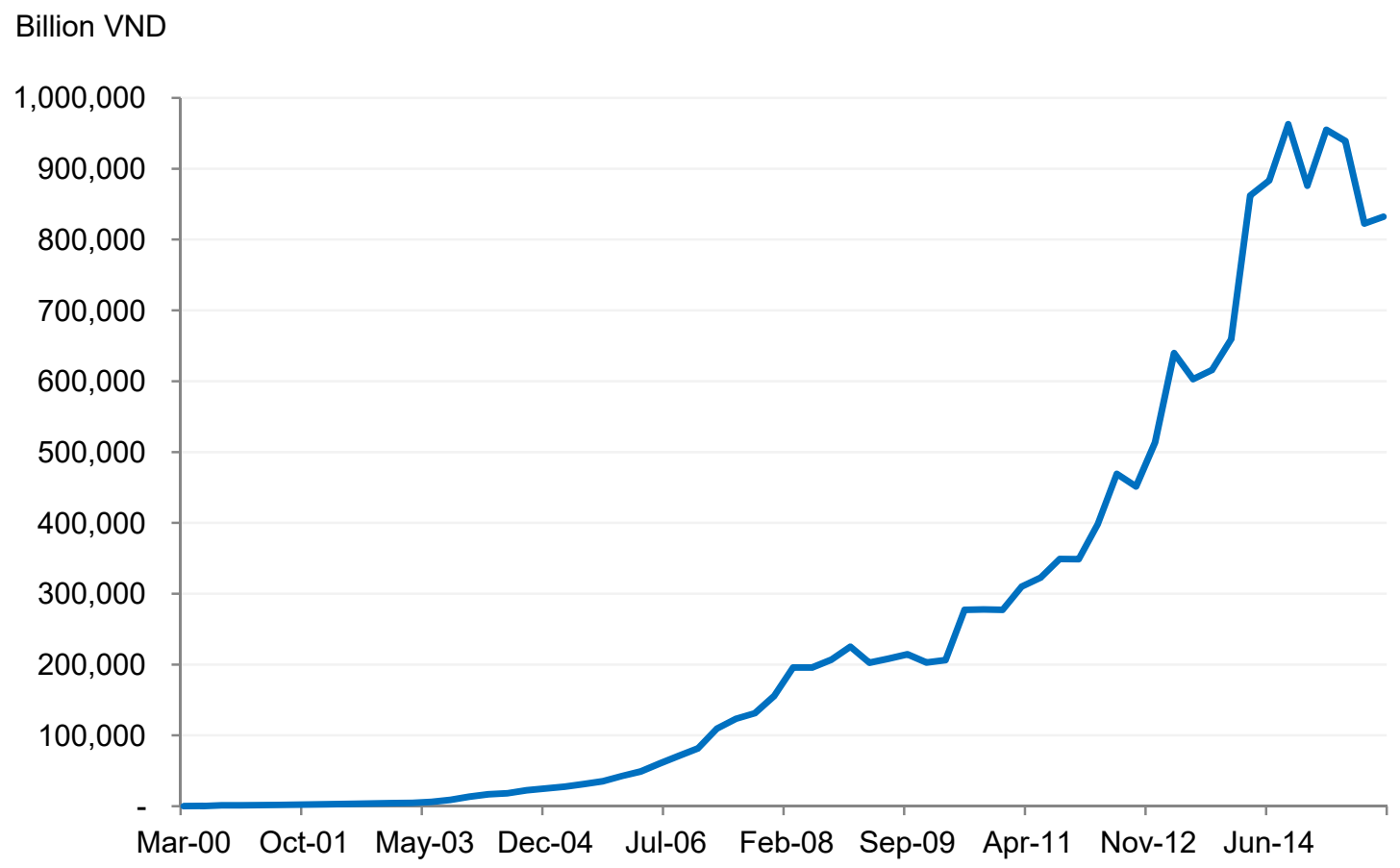

Source: ADB/Asian Bond Online (accessed March 23, 2016)

In 2011, the bond market was worth $15 \%$ GDP, with >90\% being government bonds. The total value of outstanding government bonds is now estimated $22 \%$ of GDP. Thus bonds have become a major source for financing state budget deficit.

Figure 22. Corporate bonds (outstanding)

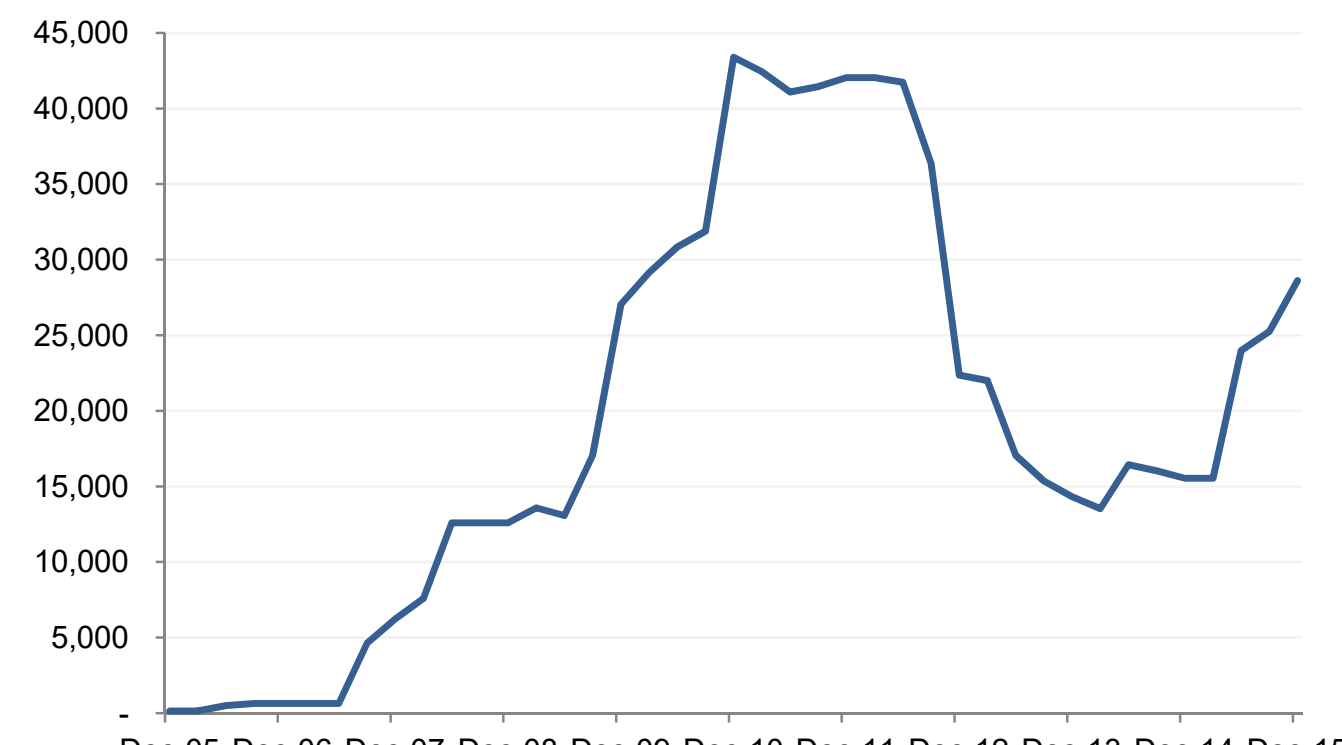

Dec-05 Dec-06 Dec-07 Dec-08 Dec-09 Dec-10 Dec-11 Dec-12 Dec-13 Dec-14 Dec-15

Source: ADB/AsianBondOnline (accessed: March 23, 2016) 
While the government bond market has been picking up since 2005, the corporate bond market remains quite modest. The corporate bond is the game where few large corporations-banks included-dominate and seek to tap public sources of debt finance.

\section{M\&A market:}

M\&A activities started in Vietnam mid-1990s. The risk spillover during the 1997 Asian financial turmoil triggered early transactions such as the merger between Phuong Nam JSCB and Dong Thap Rural JSCB in 1997. The first noteworthy cross-border M\&A deal was Colgate Palmolive's acquisition of Da Lan Toothpaste-then occupying a 30\% market share-for US $\$ 3$ million. But the real surge in M\&A activities started in 2006, speculating on Vietnam's continuous prosperity post-WTO, with 47 deals completed, worth total US $\$ 0.6$ billion.

Figure 23. M\&A in Vietnam

Billion US\$

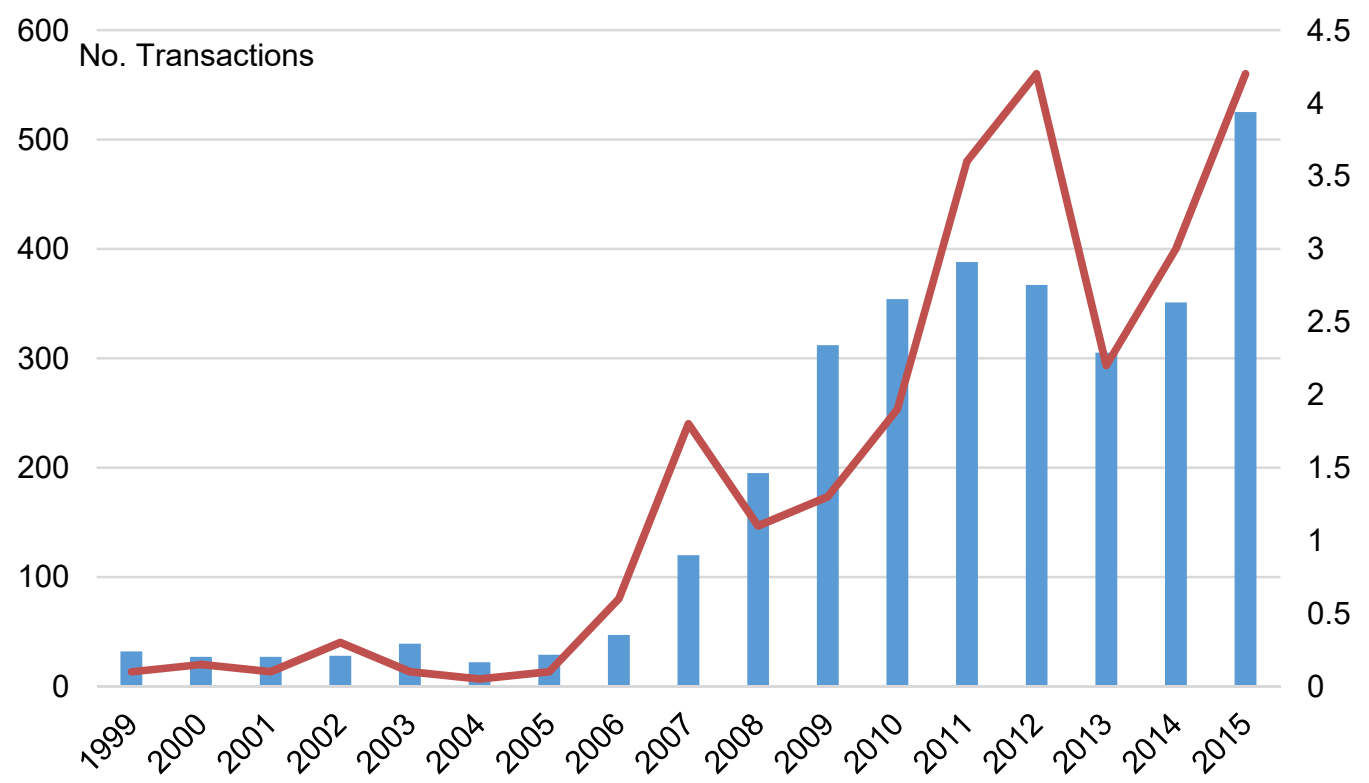

Source: IMAA

More deals completed in 2007: 120; totaled US\$1.8 billion. M\&A transactions have since made a multi-billion-dollar market with hundreds of completed deals each year as more firms wanted to acquire assets, brands or accesses to emerging lucrative market segments (Vuong, Napier \& Samson 2014).

Larger M\&A deals appeared in 2013 with Warburg Pincus's acquiring 20\% of Vincom Retail and KKR's US $\$ 400$ million purchase of Masan's equity. The market peaked in 2012 and 2015, with total value each year standing at US\$4.2 billion, counting 367 and 525 deals, respectively. M\&As among domestic firms was increasing during 2008-2012, from $22 \%$ to $45 \%$ of the market. Acquiring firms from Japan, Singapore, South Korea, and the U.S. dominate the market. 
Table 15. Typical M\&A deals in 2014-2015

\begin{tabular}{|c|c|c|c|}
\hline Transaction & Complete & Value & Remarks \\
\hline $\begin{array}{l}\text { Southern } \\
\text { Bank/Sacombank }\end{array}$ & $5 / 2015$ & $\begin{array}{l}\text { Post-M\&A Sacombank's } \\
\text { assets/capital: } \\
\text { US } \$ 13.2 \mathrm{bn} / \mathrm{US} \$ 838 \mathrm{mn} .\end{array}$ & $\begin{array}{l}\text { Sacombank in tier-1 JSCBs; } \\
\text { > } 560 \text { offices in } \\
\text { Vietnam/Laos/Cambodia; } \\
>15,500 \text { workers. }\end{array}$ \\
\hline $\begin{array}{l}\text { BIDV/Mekong Housing } \\
\text { Bank }\end{array}$ & $5 / 2015$ & US\$156mn merger. & $\begin{array}{l}\text { Post-merger BIDV's } \\
\text { capital/assets: } \\
\text { US } \$ 1.63 \mathrm{bn} / \mathrm{US} \$ 33.33 \mathrm{bn} \text {. } \\
>1,000 \text { branches/offices. }\end{array}$ \\
\hline VietinBank/PG-Bank & $5 / 2015$ & $\begin{array}{l}\text { US } \$ 143 \mathrm{mn} \text { merger; adding } \\
\text { US } \$ 1.19 \mathrm{bn} \text { to VietinBank's } \\
\text { assets. }\end{array}$ & $\begin{array}{l}\text { Post-merger Vietinbank's } \\
\text { assets/capital: } \\
\text { US } \$ 31.7 \mathrm{bn} / \mathrm{US} \$ 1.85 \mathrm{bn} \text {. }\end{array}$ \\
\hline $\begin{array}{l}\text { Maritime } \\
\text { Bank/Mekong } \\
\text { Development Bank }\end{array}$ & $8 / 2015$ & $\begin{array}{l}\text { Total assets worth } \\
\text { US } \$ 5.38 \mathrm{bn} / \text { Equity } \\
\text { US } \$ 560 \mathrm{mn} \text {. }\end{array}$ & $\begin{array}{l}\text { The merger was part of the } \\
\text { banking consolidation plan by } \\
\text { the SBV. }\end{array}$ \\
\hline $\begin{array}{l}\text { Credit } \\
\text { Saison/HDFinance }\end{array}$ & $5 / 2015$ & $\begin{array}{l}\text { US } \$ 185 \mathrm{mn} \text { for } 49 \% \text { HD- } \\
\text { Finance. }\end{array}$ & $\begin{array}{l}\text { Credit Saison/Mizuho } \\
\text { Financial Group to expand in } \\
\text { ASEAN. }\end{array}$ \\
\hline $\begin{array}{l}\text { FairFax Asia/BIDV } \\
\text { Insurance (BIC) }\end{array}$ & $4 / 2015$ & $\begin{array}{l}\text { US } \$ 50 \mathrm{mn} \text { for } 35 \% \text { BIC } \\
\text { equity. }\end{array}$ & $\begin{array}{l}\text { BIDV offered } 41 \text { million } \\
\text { shares to FairFax. }\end{array}$ \\
\hline $\begin{array}{l}\text { Dongbu/Post\&Telecom } \\
\text { Insurance (PTI) }\end{array}$ & $5 / 2015$ & US $\$ 45.8 \mathrm{mn}$ for $37 \%$ PTI. & $\begin{array}{l}\text { PTI holds }>7 \% \text { of the } \\
\text { US } \$ 1.6 \mathrm{bn} \text { property insurance } \\
\text { market. }\end{array}$ \\
\hline Smartlink/Banknetvn & $12 / 2014$ & Merger & $\begin{array}{l}\text { Merger forming a nationwide } \\
\text { system serving: } 51 \\
\text { banks/NBFIs, } 16,000 \text { ATM, } \\
105,000 \text { POS, } 55 \text { million cards, } \\
70 \text { million switching } \\
\text { operations/year. Potential } \\
\text { revenue: US } \$ 4 \mathrm{bn} / \text { year. }\end{array}$ \\
\hline $\begin{array}{l}\text { Public Bank } \\
\text { Berhad/BIDV }\end{array}$ & $7 / 2014$ & $\begin{array}{l}\$ 62.5 \mathrm{mn} \text { for } 50 \% \text { equity of } \\
\text { VID Public Bank JV. }\end{array}$ & $\begin{array}{l}\text { PBB Malaysia acquired } 50 \% \\
\text { equity holding by BIDV in VID- } \\
\text { Public to establish PBB } \\
\text { Vietnam } 100 \% \text {-FOC. }\end{array}$ \\
\hline VPBank/TKV-CMF & $6 / 2014$ & $\begin{array}{l}\text { VND1000bn for } 100 \% \\
\text { acquisition of TKV-CMF. }\end{array}$ & $\begin{array}{l}\text { State-run coal/bauxite mining } \\
\text { conglomerate TKV required to } \\
\text { exit from non-core business } \\
\text { investments. }\end{array}$ \\
\hline
\end{tabular}

\section{Banking-finance-economic growth}

\section{Interconnectedness}

The relationship between financial markets and long-term economic growth has been rich in the literature. Empirical results suggest that well-functioning system contributes to economic growth by amassing financial resources and allocating them to sectors that can use them productively (Leung 2009; Vuong \& Napier 2014). Financial markets can also provide tools and signals that help monitor the economy's efficiency and changing risks, and redirect resources under specific economic mechanisms. The financial 
tools are also behind a great number of techniques and paradigms for bettering corporate governance and promoting trade.

Financials guide firms' behavior based on their opportunity of accessing an external source of finance (O'Toole \& Newman 2012). Better access to finance, associated with a reasonable cost of funds, would likely reduce both operating and opportunity costs of firms, and hence improve business outcome. Technology transfer also requires the smooth functioning of the financial system. If this occurs in society in large scale, well-functioning financial markets will contribute to long-term economic growth; Credit/GDP and M2/GDP increases show some positive effect on Vietnam's growth in the 1997-2006 period (Anwar \& Nguyen 2009). Also, FDI efficiency shows some evidence of reliance on the efficiency of the financial markets. Thus financial factor has both direct and indirect effects on economic growth of Vietnam.

Vietnam's leadership now considers steps of liberalizing the financial system, giving more freedom to market players. Although the government's interventions are still unavoidable sometimes, they are now used more cautiously, and policymaking tends to be increasingly evidence-based.

Figure 24. Average lending rates

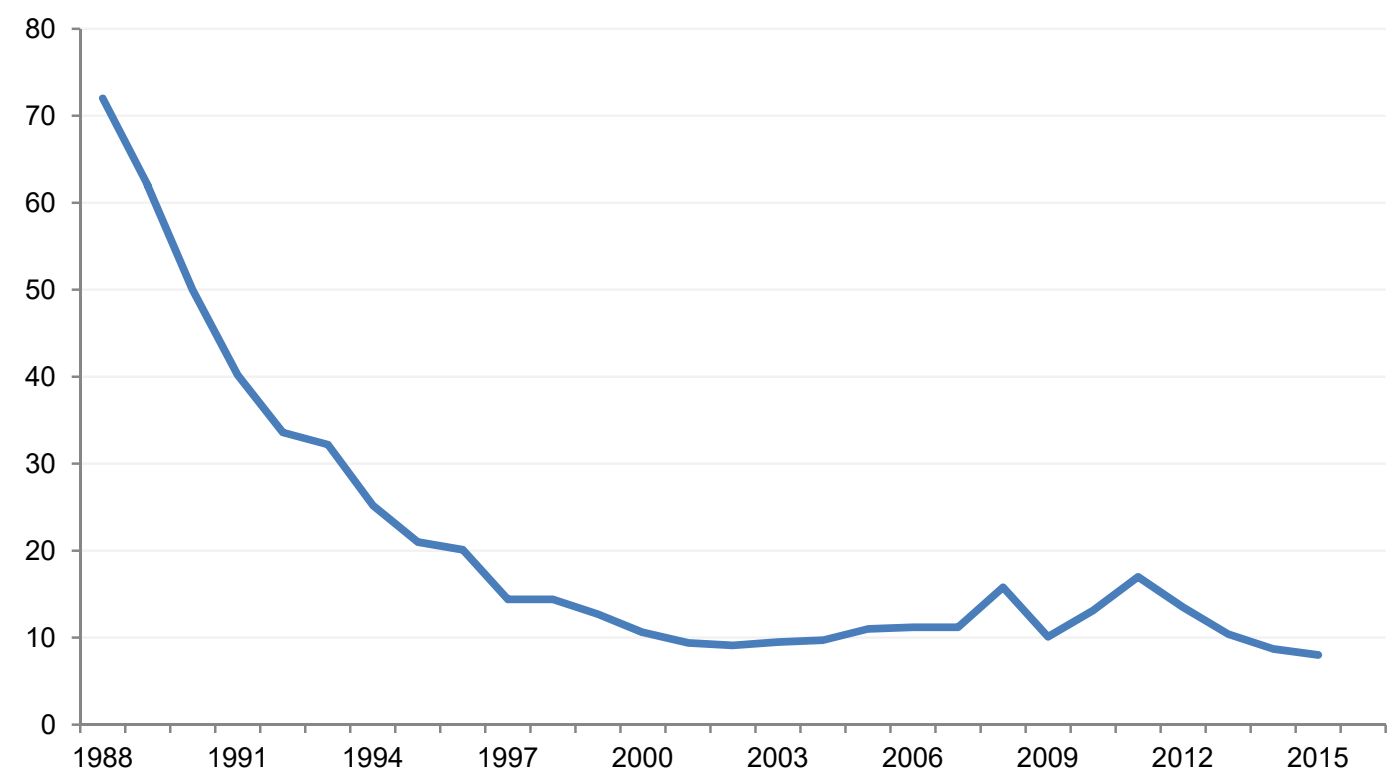

Increases in M2 induce increasing outputs through thanks to reduced costs and more investments in the productive sector as Hung \& Pfau (2009) provide evidence that money shock is responsible for as little as $0.64 \%$ of shock in prices, but for over $44 \%$ of real output increase in the short run. But as both the capacity of absorbing money and the technical efficiency by productive sector are bounded, too much finance by later decrease economic efficiency (Vuong \& Napier 2014). Passing some thresholds of size/growth, the financial sector tends to compete with the rest of the economy for resources and its enlargement is no longer growth-enhancing (Nguyen, Le \& Freeman 2006; Cecchetti \& Kharroubi 2012).

In addition, with the existence of stock markets, integration into the world economy increases interdependency among capital markets and contagion risks. There is evidence 
that VSM has been influenced by American, Chinese and Japanese stock markets, of which risks spillover from the Japanese stock market was found to be the strongest (Wang \& Lai 2011). Also, Pham \& Riedel (2012) argue that the conduct of monetary policy in Vietnam during the higher inflation period was generally 'clumsy'. Management of foreign exchange fluctuations has been a burden on SBV/SOCBs, limiting the ability to pursue an independent monetary policy. Financial sector liberalization helps promote not only growth but also macroeconomic stability.

\section{Inclusive financing: microfinance-venture capital-crowdfunding}

\section{Microfinance:}

Jobs creation has been a major economic achievement. From the mid-1990s, most jobs have been created by the private SMEs. The problem with the SMEs subsector has been a constant lack of access to financing and unequal playing field where they are subjected to higher costs of fund and operations (O'Toole \& Newman 2012; Yoshino \& TaghizadehHesary 2014). Kalra (2015) reports only $8 \%$ of Vietnamese saved money and $16 \%$ had a loan with a financial institution in 2011.

In a context that $30 \%$ of adults borrowed from friends/family and that among the poorest income quintile in Vietnam, only 6\% had access to formal financial services (Kalra 2015), seeking microfinance is perhaps a logical consequence. Microfinance has now been one of the important solutions and a sign of financial market liberalization, although evidence on positive effects of microfinance has been mixed (IFC 2014). The presence of microfinance institutions (MFIs) and microfinance activities can be traced back to 1980s under various formal and informal types of financing such as credit cooperatives, 'Hui' or small group's alternate borrowings. By mid-1996, 674 people's credit funds collectively gathered about 275,000 members, mobilizing US $\$ 48$ million funds and lending out US\$67mn (Fallavier 1998).

However, the concept of formal microfinance appeared in the early 1990s, and its credit-based schemes were first implemented under donor-funded programs. Microcredit has usually been associated with inherent services such as access to saving facilities and provision of basic insurance (Vuong 2010). Nonetheless, the commercial viability of MFIs has always been a question due largely:

i) relatively high administrative costs;

ii) riskier due to lack of management resources and standard governance;

iii) lack of collaterals by borrowers, leading to a propensity to increase interest rates.

Hainz, Dinh \& Kleimeier (2011) present evidence that richer credit borrowers tend to succeed in securing larger loan amounts, reducing 'friction' and paying lower costs of the fund while access to fast-improving banking infrastructure is still limited within the uppermiddle-income class, mainly residents of major cities. According to IFC (2014) only $16.5 \%$ of the adults in rural areas, and $29.8 \%$ of adults in urban areas have an account at a formal financial institution as of 2011, whereas the averages for the East Asia \& Pacific developing region are $50.1 \%$ and $68.7 \%$, respectively.

Although still limited in scale, improvements of MFI activities can be seen with more recent statistics. The three major domestic systems that are partly responsible for microfinance activities, namely VBSP, VBARD, PCFs collectively served 9.6 million clients by the end of 2013, providing a total amount of credit worth US\$8,034 million. While it is still 
not easy to learn about genuine microcredit portion of this portfolio, by the end of 2012, genuine MFIs (exclusive of VBSP/VBARD/PCFs) provided US $\$ 108$ million microcredit to 480,000 clients (IFC 2014). This cause of sustainable development-supported by multilateral organizations-also leads to microfinance initiatives such as ADB-managed US\$40mn ADF program in conjunction with the Japan Fund for Poverty Reduction's technical assistance. ${ }^{[2]}$

\section{Venture capital financing:}

Due to the predominant credit-based financing agenda by the Vietnamese government, venture-capital activities had a slow start in the 1990s, and Vietnam's entrepreneurial financing initiatives have significantly diverged from international venturecapital policy patterns (Klingler-Vidra 2014). Today's best known venture-capital funds (VCF) include IDG Ventures Vietnam, Kamm Investment, CyberAgent Ventures, DFJ VinaCapital, Indochina Capital, Mekong Capital, Vietnam Partners.

IDGVV is the pioneer with its presence in Vietnam dated back in 1992, with IDG financing PCWorld Vietnam-first computer publication. Formally established in 2004, it now holds a portfolio of US $\$ 100$ million investments in 42 technology, ICT/Media and consumer sector companies, including such successful projects as VNG, Apollo, VC-Corp, VietnamWorks.

In 2015, the government also explored the opportunity of setting up a VCF to support newborn ecosystem for tech-related entrepreneurs, with assistance from statefinanced sci-tech supports agencies such as NAFOSTED/NATIF/NATEC, Vietnam Startup Fund, and Vietnam Silicon Valley Project. Still, there is a lack of local funds so that earlystage tech startups are underfinanced. The government and its research institutes believe a national VCF will be a prime solution, helping nurture this critically important component of the entrepreneurship ecosystem with seed funding.

In March 2016, 500-Startups announced its plan to set up a US\$10 million VCF focused on Vietnam-connected startups. The typical investment in a startup venture runs from US $\$ 100,000$ to 250,000 . Apart from the finance, the fund intends to support startups with their international network of 3,000 mentors and founders, and credit facilities with such partners as Amazon and Facebook.

Still, the venture-capital industry remains modest and underdeveloped despite a batch of emerging VCFs that have come into existence since the 2000s (Klingler-Vidra 2014).

\section{Crowdfunding:}

This financing mechanism has become a buzzword over the recent years when entrepreneurship programs seek to find alternative finances for entrepreneurs' creative, yet risky, ideas (Vuong 2016a, 2016b). The AEC is expected to attain US\$8 billion market for crowdfunding in the latter half of the 2010s when the world's crowdfunding industry reaches US\$96 billion in size. It was heard of for the first time in Vietnam in 2012, but the legal framework for governing crowdfunding operations has not been in place leading to higher perceived risks. Vietnam's finally got the first ever crowdfunding platform IG9 in mid-2013.

Most crowdfunding activities center around a handful of Internet-based platforms: ig9.vn, fundstart.vn, 500.co, inspireventures.com, cyberagentventures.com... Despite its novelty, local entrepreneurs are receptive to crowdfunding and on steep learning curves. By 
2016, this entrepreneurial finance concept has become somewhat familiar, offering key values of:

- Increasing awareness and helping to build trust gradually;

- Getting around strict collateral requirements;

- Testing if new projects are perceived as well by the larger community;

- Facilitating the communications and connecting startups to different circles in society.

The crowdfunding industry has still been nascent, but it appears that with the fast increasing entrepreneurship community and receptive entrepreneurs, Vietnam would likely become the second country in ASEAN-after Malaysia-to institutionalize a crowdfunding framework with a development roadmap.

\section{Inherent risks and challenges}

VFS's bank-based nature induces inherent risks of structural problems as, at present, total banking assets-SPBs included-amount to $180 \%$ of GDP, and $>92 \%$ of VFS's assets. Additionally, during 2005-2010, state institutions increased holdings in SOCBs/JSCBs from VND 1 trillion to 15 trillion without facing any regulatory restrictions (Pincus 2015), although inefficiencies of state-owned non-core investments had been well-informed. Meanwhile, the inflation problem remains, making the system even more vulnerable to economic shocks (Vuong 2010; Nguyen, Cavoli \& Wilson 2012; Kalra 2015).

Too much power of the financial sector also likely leads to the situation where financial institutions compete with productive sectors for resources, increasing the risk of misallocation (Stiglitz 2016). Addiction to financial resource is also real. In addition, resource without innovative capacity and value-added activities by companies becomes a drag on the corporate sector-a kind of financial "resource curse"-through destructive creation of resource-rich, uninnovative and rent-seeking quasi-business organizations (Vuong \& Napier 2014). Rampant practices of directed lending and relationship-based credit granting further add to the increased risk of financial failures, or worse off, financial frauds (Vuong, Napier \& Tran 2013; Vuong 2016a,b).

Use of credit in Vietnam has generally been regarded as inefficient. The real estate market consumed $80 \%$ of credit supply in 2013, crowding out other productive sectors of the economy. More recently, government's economic stimulus package in 2008 induced risk-taking behaviors and arbitrage opportunities holders of speculative assets, potentially causing risks of overinflating bubbles in real estate and financial assets markets (Dinh, Malesky, To \& Nguyen 2013). The risk of misallocation of finance increased substantially in the context that only $20 \%$ of finance for entrepreneurs/SMEs was informal, pushing costs of the fund to 3-6 times of the formal banking rates (Thanh, Cuong, Dung \& Chieu 2011). This is a serious issue for the Vietnamese economy in general (O'Toole \& Newman 2012). Selfish commercial interests tend to entice banks-currently under interest controls-to protect their margins by transferring operational costs to customers (Pham 2015). The banking sector also encountered numerous scandals that led to jail terms for many senior bankers (Table 16 provides some examples).

Table 16. Noticeable arrests of bankers

\begin{tabular}{|l|l|l|l|}
\hline Name & Position & Bank & Year \\
\hline
\end{tabular}




\begin{tabular}{|l|l|l|r|}
\hline Pham Quyet Thang & CEO & GP-Bank & 2016 \\
\hline Huynh Nam Dung & Chair/BOD & MHB & 2016 \\
\hline Nguyen Xuan Son & Chair/BOD/PetroVietnam & OceanBank & 2015 \\
\hline Nguyen Minh Thu & Chair/BOD & OceanBank & 2015 \\
\hline Do Tat Ngoc & Chair/BOD & Agribank & 2014 \\
\hline Ha Van Tham & Chair/BOD & OceanBank & 2014 \\
\hline Phan Thanh Mai & CEO & VNCB & 2014 \\
\hline Pham Cong Dan & Chair/BOD & VNCB & 2014 \\
\hline Pham Thanh Tan & CEO & Agribank & 2013 \\
\hline Do Hung So & Director/Hau Giang Office & LienVietbank & 2013 \\
\hline Tran Xuan Gia & Chair/BOD/Former Minister of MPI & ACB & 2012 \\
\hline Nguyen Duc Kien & Co-founder & ACB & 2012 \\
\hline Nguyen Thi Huong Gian & Vice-CEO & SeaBank & 2012 \\
\hline Huynh Thi Huyen Nhu & Deputy Division Chief & VietinBank & 2012 \\
\hline
\end{tabular}

Another persistent challenge is habitual practices of using a large portion of shortterm funds to provide long-term credit, causing mismatch risk and adversely affecting assetliability management (ALM) equations. The ratio changed for SOCBs over time from $21.5 \%$ (2012) to 25\% (2014) and 34\% (2016); and for JSCBs: 18\%, 21\%, 37\%, respectively. The issue appears to worsen even though the size of the banking system has increased significantly. Thus a structural issue remains structural!

In reality, realizations of the risks mentioned above are reflected through the imminent problem of non-performing loans (NPL) within VFS. Official bad debt ratioprovided in Fig. 25-is usually regarded by experts as well below international standards, triggering disagreements even among concerned authorities.

Figure 25. VFS's bad debt ratio 


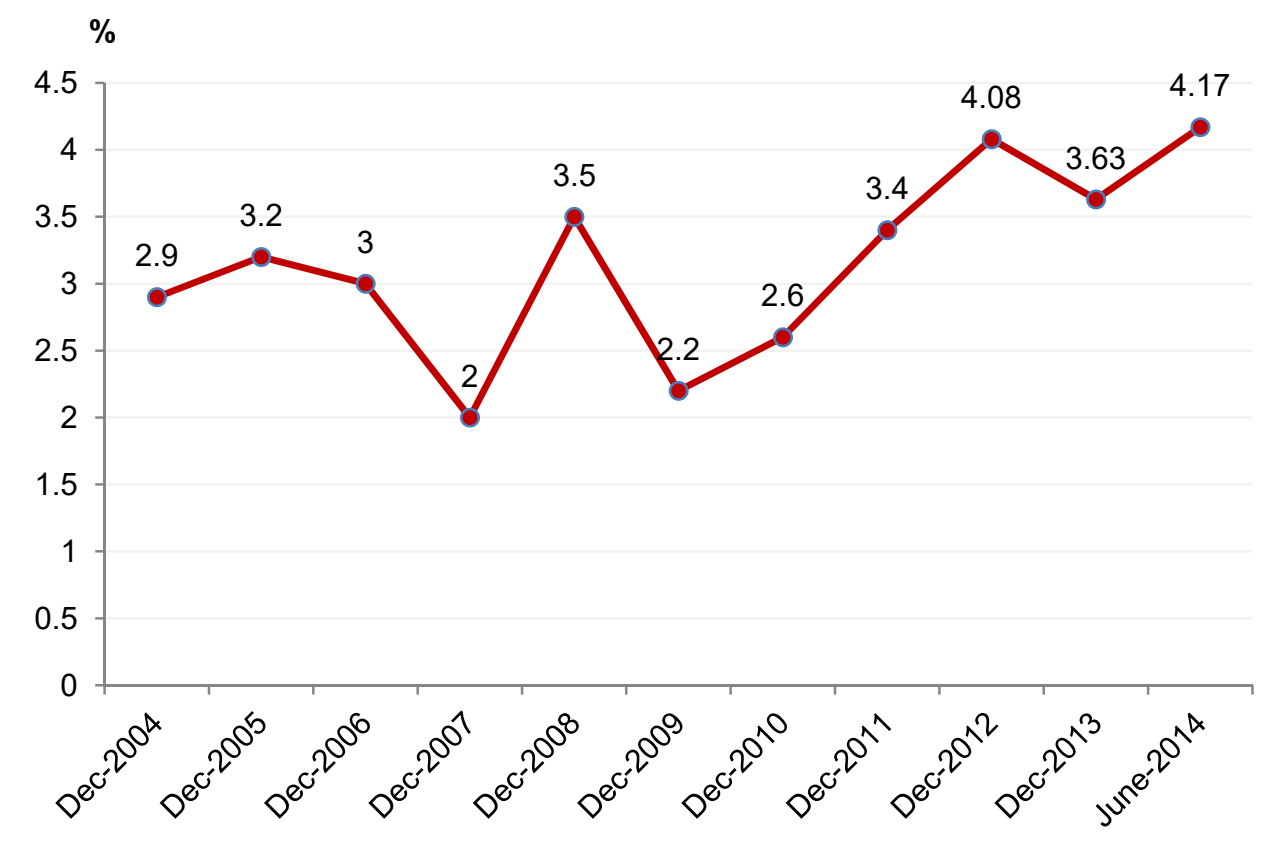

Source: SBV reports

The creation of VAMC and its questionable credibility show how serious the problem of bad debts is. Without an essential solution, this deeply rooted problem would further increase risk appetite by the rich firms, especially those in speculative assets markets. Needless to say, the information asymmetry problem, nested in banks' cross-holding of banks' equity, would make the risk skyrocket (Pincus, 2015).

Facing these issues, recent positive signs of the banking system such as a lower Lending-to-Deposit Ratio (LDR) of around 80\% during 2014-2016, and positive growth rate of deposits at banks may serve as the system's pain reliever for some time. However, the signs may, unfortunately, reflect the truth of a lower capacity to consume finance within the productive sector and society's liquidity preference, even though interest-earning capacity decreases.

Fig. 24 shows that over the past decades, commercial lending rates in Vietnam have been constantly high, rarely below $10 \%$ p.a. Among banks, their interbank borrowings show wildly-fluctuating costs of the fund. And, each short period of lower costs of the fund was followed by a longer period with rate jumps (Fig. 26), evidence of liquidity-crunch and ALMrisk amplification. This phenomenon is a real threat to any large and long-term project as it makes financial calculations uncertain and risky. 
Figure 26. 3-Month Interbank Rate

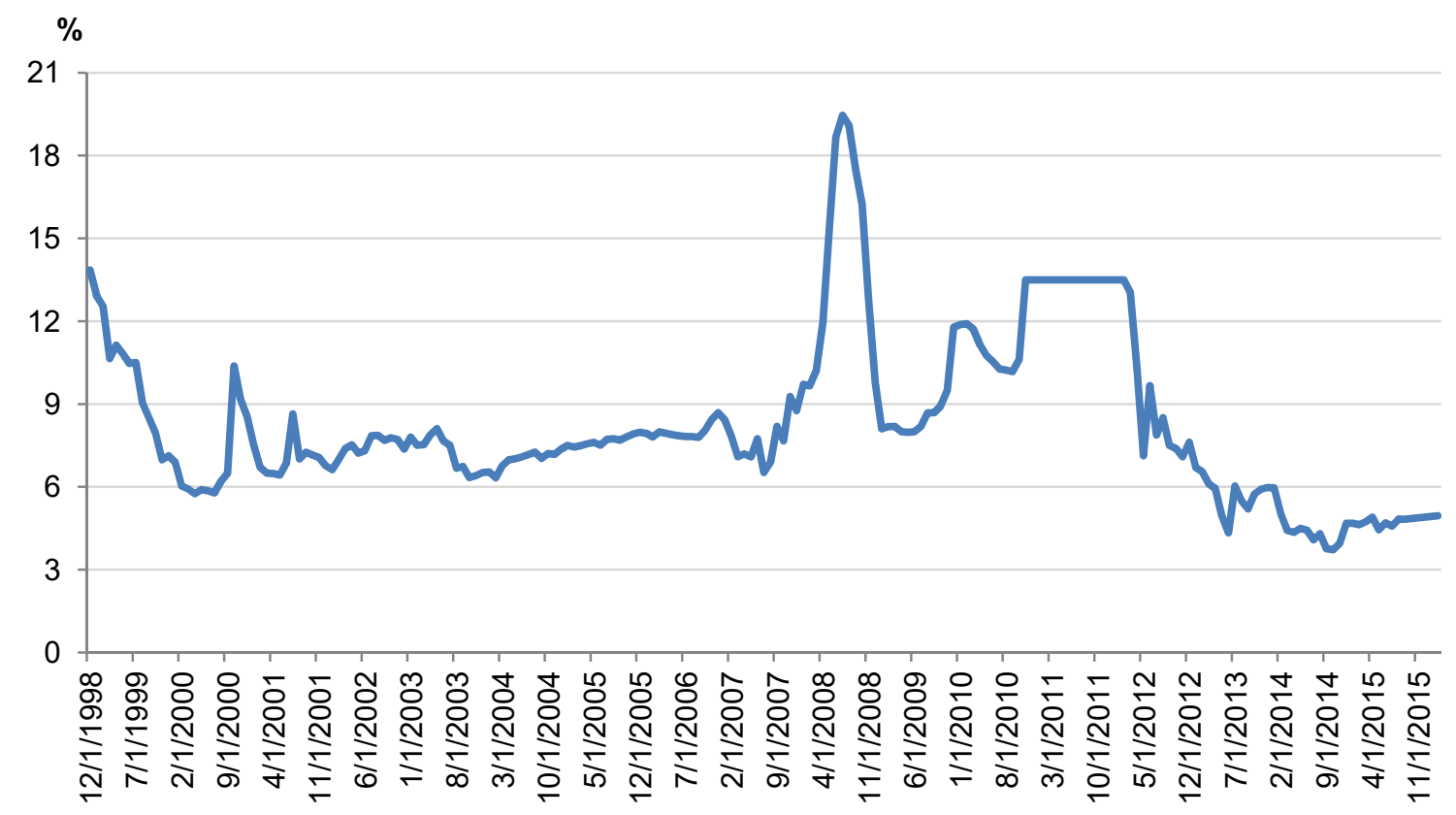

Data source: State Bank of Vietnam.

With the AEC coming into existence from December 31, 2015, new challenges also arrive. By 2015, ASEAN enterprises have registered a total FDI-capita stock of US $\$ 57$ billion $(2,700$ projects), surpassing South Korea (US $\$ 45$ billion/4,020 projects), Japan (US $\$ 38$ billion/2,700 projects). Regional players are taking up the opportunity to strengthen their standing in VFS (Skully \& Perera 2012). A typical example is Public Bank Berhad's swift move to close its 20-year-old VID Public Bank JV with BIDV to establish its locally-registered wholly-owned banking entity. That augurs for a coming competition, whose complexities and fierceness may not be fully appreciated by domestic FIs (Vuong 2016a).

\section{Reform needs}

It is generally agreed that financial reforms have to a large extent supported the transformation of Vietnam's economy (Kovsted, Rand \& Tarp 2005; Bayraktar \& Wang 2006; ADB 2014; WB 2014). And, persistent problems-as having been observed-are now putting pressure on VFS to renew reforms (Leung 2009; Tra \& Riedel 2012).

$\# 1$ : The structural problem of the financial sector will need to be addressed adequately, as the with fast-growing assets of the sector-now already $200 \%$ of Vietnam's GDP-all structural problems pertaining to its subsectors will be amplified, making the economy increasingly vulnerable to economic shocks (ADB 2014, 2015). Vietnam's financial deepening is quite high compared to the majority of lower middle-income countries. Although VFS openness improves access to financial services and the efficiency of financial intermediaries (Bayraktar \& Wang 2006), its functions of reducing the cost of funds and stimulating capital accumulation/economic growth face serious limitations. Therefore, the opening of the sector does not suffice to address the structural problem, following evidence 
on VFS itself (Leung 2009; Nguyen \& Nguyen 2009; Vuong 2010; Tra \& Riedel 2012). Renewed reforms of the governance system based on rules of law and arm's-length transactions principle will have to be institutionalized (Malesky \& Taussig 2009; Bhattacharya 2014; Pincus 2015). That means a departure from the existing systemprimarily based on personal relationships, cronyism, and unchecked commercial interestswith cross-holdings of banks' equity as a manifestation (Sarath \& Pham 2015).

\#2: The clumsiness of local monetary policy in troubled times (Tra \& Riedel 2012) is related to the complexity, and most probably the impossibility, of its multi-objective macro decision-making framework, thus a reform need is well beyond just fixing the "clumsy policy behavior" (Nguyen \& Nguyen 2009; Nguyen, Cavoli \& Wilson 2012; Kalra 2015). The two bouts of 2-digit inflation during 2008-2012 remind policymakers of the "impossible trinity" doctrine, in several variants (Das 2006; Grenville 2011).

The concept "reforming the reform" may be particularly useful as Vietnam's transitions would shortly enter unchartered waters of the unprecedented pace of regionalization and globalization (Stiglitz 2016). While complications and uncertainties prevail, the sociocultural system with its well-built mindset finds them uncomfortable to cope with (Yu 2008; Vuong \& Napier 2015; Vuong, Vu, and Vuong 2016.). Public debts reaching the dangerous limit, vulnerable financial system, constantly constrained budgets coupled with large deficits will certainly put Vietnamese leadership at a serious stress test, where the dichotomy of policy choice is as simple as:

a) moving forward with reformist political economy principles; or,

b) moving backward to stricter control for the illusion of independence and autonomy bearing the immeasurable cost of foregone opportunities (Kokko 1998; Presbitero 2008; Volz 2013).

\#3: The weaknesses that prevent the economy from attaining its optimal balance between growth and sustainability include:

a) inadequate speed of institutional reforms, macro institutions and entrepreneurial ecosystem included; and,

b) the lack of an autonomous central bank with effective policy-making and efficient set of policy implementation tools, which has the skills, rules, resources, and capabilities of balancing between stability-oriented interventions and profitable risk-taking (Carmen 2006; Kraay \& Nehru 2006; Leung 2009; Volz 2013).

In the age of indebtedness and deficits, SBV's relative independence will even be more critical as compromising on the quality of policy-making will ultimately lead to uncontrollable risks and failures to plan even in the short run. As the monetary and capital markets have already been strongly connected and very sensitive even to a vague sign of failures (Bellocq \& Silve 2008), monetary policy quality will have far-reaching effectspositive or negative-on the whole economy and its future. Toward such a reform, the value of increasing central bank's autonomy should ultimately be for public interests and national sustainable prosperity (Stiglitz 2016).

Analysts may have different views about Vietnam's financial economy, but all agree that it has evolved and grown fast over the past three decades in transition. The next course of development will depend on how Vietnamese society views raison d'être of VFS. Failure to support a sustained growth puts VFS's existence at risk as economic growth helps mitigate 
higher risk-taking behavior and contain instability in less competitive markets (Soedarmono, Machrouh \& Tarazi 2011).

\section{Acknowledgments}

The author extends his gratitude to V\&A Research Staff-Dam Thu Ha, Do Thu Hang, Vuong Thu Trang-for their assistance in preparing data for this chapter. He is also grateful for several experts that have helped form his view of a functioning financial system: Nancy $\mathrm{K}$. Napier (Boise State University), André Farber, Ariane Szafarz (Université Libre de Bruxelles), James Riedel (Johns Hopkins University), Joseph Stiglitz (Columbia University) and Nguyen Pham Muoi (Wall Street Journal).

\section{Notes}

[1] Financials reported in US\$ are for comparison while actual reporting of Vietnamese national accounts and market transactions is stipulated by laws to use the Vietnamese Dong (VND).

[2] ADB/ARIC <https://aric.adb.org/macroindicators/userdefined>, (accessed: 20/2/2016); WDI <http://data.worldbank.org/indicator/DT.DOD.DECT.CD>.

[3] ADB/NewsBrief (5/7/2012). <http://www.adb.org/news/briefs/viet-nam-microfinancedevelopment-program>

\section{Appendix}

A1. Inflation and GDP Growth, 1986-2015

\begin{tabular}{|lrr|rrr|rrr|}
\hline Year & $\begin{array}{c}\text { Inflation } \\
(\%)\end{array}$ & $\begin{array}{c}\text { GDP } \\
\text { Growth (\%) }\end{array}$ & \multicolumn{2}{c|}{$\begin{array}{c}\text { Year } \\
(\%)\end{array}$} & $\begin{array}{c}\text { Inflation } \\
(\%)\end{array}$ & $\begin{array}{c}\text { GDP Growth } \\
\text { (\%)ar }\end{array}$ & $\begin{array}{c}\text { Inflation } \\
(\%)\end{array}$ & $\begin{array}{c}\text { GDP Growth } \\
(\%)\end{array}$ \\
\hline 1986 & 748.00 & 2.84 & 1996 & 4.50 & 9.34 & 2006 & 6.60 & 6.98 \\
1987 & 223.00 & 3.63 & 1997 & 3.60 & 8.15 & 2007 & 12.60 & 7.13 \\
1988 & 394.00 & 6.02 & 1998 & 9.20 & 5.77 & 2008 & 19.89 & 5.66 \\
1989 & 34.70 & 4.68 & 1999 & 0.10 & 4.77 & 2009 & 6.52 & 5.40 \\
1990 & 67.10 & 5.09 & 2000 & -0.60 & 6.79 & 2010 & 11.75 & 6.42 \\
1991 & 67.50 & 5.81 & 2001 & 0.80 & 6.89 & 2011 & 18.13 & 6.24 \\
1992 & 17.50 & 8.70 & 2002 & 4.00 & 7.04 & 2012 & 6.81 & 5.25 \\
1993 & 5.20 & 8.08 & 2003 & 3.00 & 7.24 & 2013 & 6.04 & 5.42 \\
1994 & 14.40 & 8.83 & 2004 & 9.50 & 7.79 & 2014 & 1.84 & 5.98 \\
1995 & 12.70 & 9.54 & 2005 & 8.40 & 7.55 & 2015 & 0.63 & 6.68 \\
\hline
\end{tabular}

A2. 5-Year Government Bond Issues 


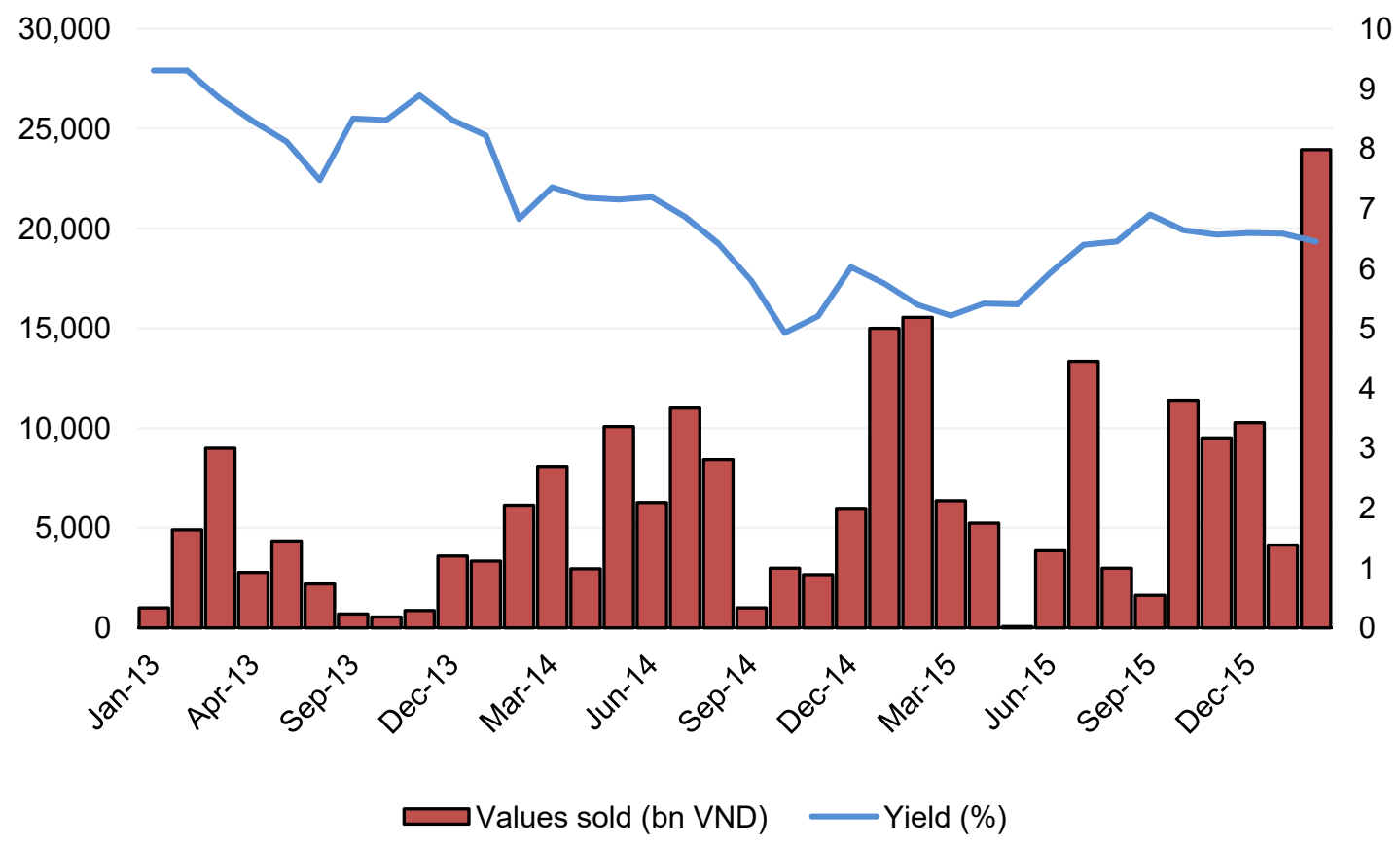

A3. 3-Year government bond issues

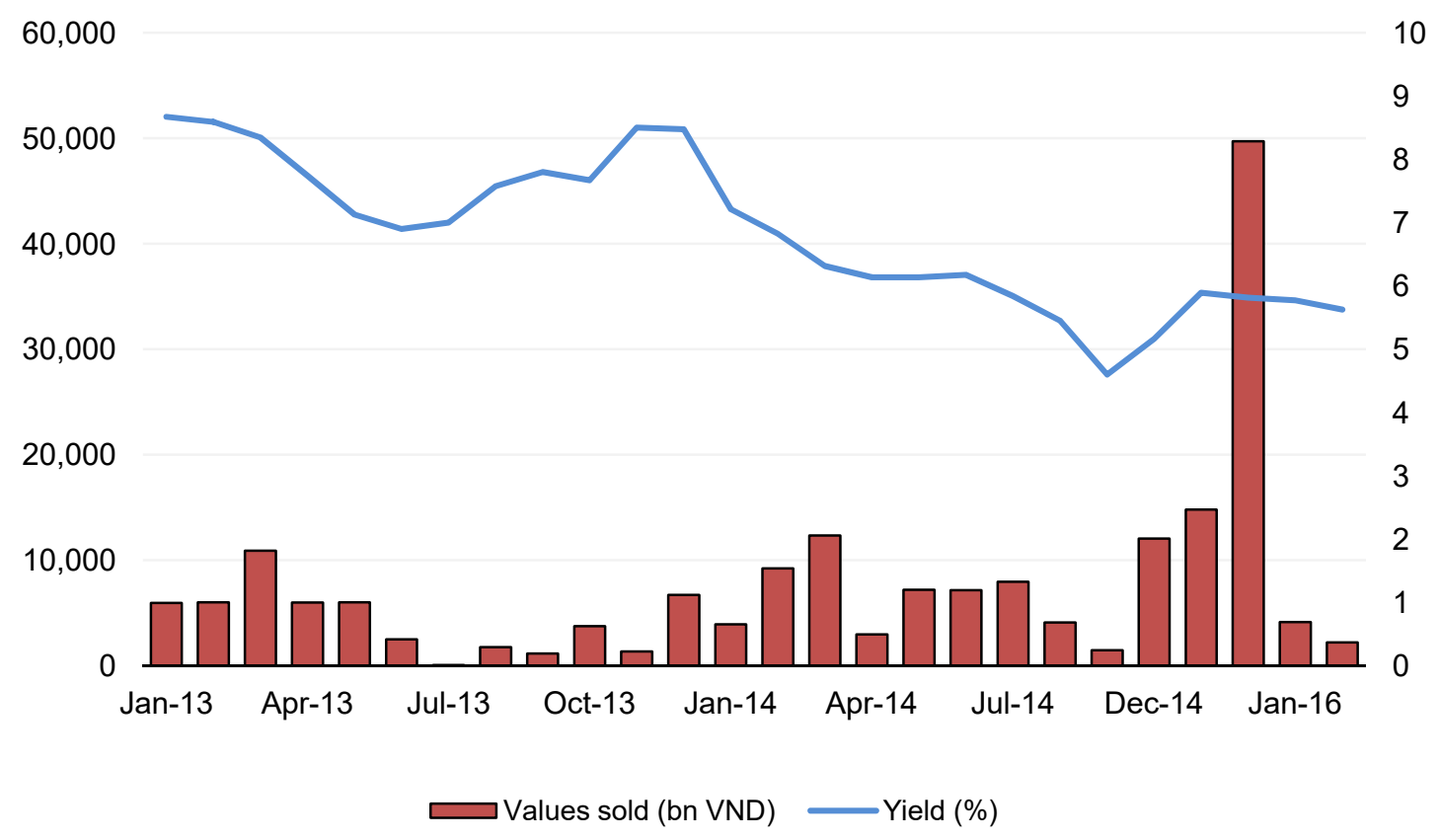




\section{Bibliography}

ADB. 2014. Viet Nam: Financial Sector Assessment, Strategy, and Roadmap. Manila: Asian Development Bank.

ADB. 2015. Key Indicators for Asia and the Pacific 2015. Asian Development Bank.

Anwar, S., and L.P. Nguyen. 2011. Financial Development and Economic Growth in Vietnam. Journal of Economics and Finance 35(3):348-360.

Bayraktar, N., and Y. Wang. 2006. Banking Sector Openness and Economic Growth. World Bank Policy Research Working Paper No.4019.

Bellocq, F-X., and A. Silve. 2008. The Banking System of Vietnam after the Accession to WTO: Transition and its Challenges. AFD Working Paper No. 77.

Bhattacharya, R. 2014. Inflation Dynamics and Monetary Policy Transmission in Vietnam and Emerging Asia. Journal of Asian Economics 34:16-26.

Camen, U., 2006. Monetary Policy in Vietnam: The Case of a Transition Country. BIS-WP.

Cecchetti, S.G. and E. Kharroubi. 2012. Reassessing the Impact of Finance on Growth.Reserve Bank of India's Second International Research Conference in Mumbai (1-2 February 2012).

Das, D.K. (2006). Globalization in the World of Finance: An Analytical History. Global Economy Journal 6(1):1-22.

De Vylder, S. and A. Fforde. 1996. From Plan to Market: The Economic Transition in Vietnam. Boulder, CO: Westview.

Dinh, T.M., E. Malesky, T.T. To, and D.T. Nguyen. 2013. Effect of Interest Rate Subsidies on Firm Performance and Investment Behavior during Economic Recession: Evidence from Vietnam. Asian Economic Journal 27(2):185-207.

Dutta, M. 1995. Vietnam: Marketization and Internationalization of its Economy. Journal of Asian Economics 6(3):311-326.

Fallavier, P. 1998. Developing Micro-finance Institutions in Vietnam (Doctoral dissertation, University of British Columbia).

Fforde, A. 2010. Rethinking the Political Economy of Conservative Transition: The Case of Vietnam. Journal of Communist Studies and Transition Politics 26(1):126-146.

Goujon, M., 2006. Fighting Inflation in a Dollarized Economy: The Case of Vietnam. Journal of Comparative Economics 34(3):564-581.

Grenville, S. 2011. The Impossible Trinity and Capital Flows in East Asia. Asian Development Bank Institute, Working Paper 318.

Hainz, C., T. Dinh, and S. Kleimeier. 2011. Collateral and its Determinants: Evidence from Vietnam. In Proceedings of the German Development Economics Conference, Berlin 2011 (No. 36). Verein für Socialpolitik.

Hoang, V.Q., \& T.T. Dung. 2009. The Cultural Dimensions of the Vietnamese Private Entrepreneurship. IUP Journal of Entrepreneurship Development 6(3/4):54-78.

Hung, L.V., and W.D. Pfau. (2009). VAR Analysis of the Monetary Transmission Mechanism in Vietnam. Applied Econometrics and International Development 9(1):165-179.

IFC. 2014. Responsible Finance in Vietnam. Report/East Asia \& the Pacific Publications.

Kalra, S. 2015. Vietnam: the Global Economy and Macroeconomic Outlook. Journal of Southeast Asian Economies 32(1):11-25.

Klingler-Vidra, R. 2014. Building a venture capital market in Vietnam: diffusion of a neoliberal market strategy to a socialist state. Asian Studies Review 38(4):582-600.

Kokko, A., 1998. Vietnam: Ready for Doi Moi II?. ASEAN Economic Bulletin 15(3):319-327.

Kovsted, J., J. Rand, and F. Tarp. 2005. From Monobank to Commercial Banking: Financial Sector Reforms in Vietnam. Singapore: Institute of Southeast Asian Studies. 
Kraay, A., and V. Nehru. 2006. When is External Debt Sustainable? The World Bank Economic Review 20(3):341-365.

Leung, S. 2009. Banking and Financial Sector Reforms in Vietnam. ASEAN Economic Bulletin 26(1):44-57.

Malesky, E.J., and M. Taussig. 2009. Where is Credit Due? Legal Institutions, Connections, and the Efficiency of Bank Lending in Vietnam. Journal of Law, Economics, and Organization 25(2):535-578.

Napier, N.K., Q.H. Vuong. 2013. Serendipity as a strategic advantage?. In Wilkinson (ed) Strategic Management in the 21st Century, pp. 175-199. Westport, CT: Praeger/ABCClio.

Napier, N.K., Q.H. Vuong. 2013b. What We See, Why We Worry, Why We Hope: Vietnam Going Forward. Boise, ID: Boise State University CCI Press.

Nguyen, H.M., T. Cavoli, and J.K. Wilson. 2012. The Determinants of Inflation in Vietnam, 2001-09. ASEAN Economic Bulletin 29(1):1-14.

Nguyen, T.P., and D.T. Nguyen. 2009. Exchange Rate Policy in Vietnam, 1985-2008. ASEAN Economic Bulletin 26(2):137-163.

Nguyen, T.V., T.B.N. Le, and N.J. Freeman. 2006. Trust and Uncertainty: A Study of Bank Lending to Private SMEs in Vietnam. Asia Pacific Business Review 12(4):547-568.

Oh, S.N. 1999. Financial Deepening in the Banking Sector-Viet Nam. In Rising to the Challenge in Asia: A Study of Financial Markets-The Socialist Republic of Viet Nam. Asian Development Bank, Manila.

O’Toole, C.M., and C. Newman.2012. Investment Financing and Financial Development: Firm Level Evidence from Vietnam. The Institute for International Integration Studies Discussion Paper Series.

Painter, M. 2005. The Politics of State Sector Reforms in Vietnam: Contested Agendas and Uncertain Trajectories. Journal of Development Studies 41(2):261-283.

Pham, H. 2015. Bank Efficiency, Ownership Structure and Regulations in Vietnam (Doctoral dissertation, Limoges).

Pham, T.T.T., and J. Riedel. 2012. On the Conduct of Monetary Policy in Vietnam. Asian-Pacific Economic Literature 26(1):34-45.

Pincus, J. 2015. Why Doesn't Vietnam Grow Faster?: State Fragmentation and the Limits of Vent for Surplus Growth. Journal of Southeast Asian Economies 32(1):26-51.

Presbitero, A.F. 2008. The Debt-Growth Nexus in Poor Countries: A Reassessment. Economics: The Open-Access, Open-Assessment E-Journal 2:30.

Riedel, J., and W.S. Turley. 1999. The Politics and Economics of Transition to an Open Market Economy in Viet Nam. OECD Development Centre. Technical Paper No.152.

Román, L. 1995. Institutions in Transition: a Study of Vietnamese Banking.(Doctoral dissertation, Stockholm School of Economics).

Sarath, D., and D.V. Pham. 2015. The Determinants of Vietnamese Banks' Lending Behavior: A Theoretical Model and Empirical Evidence. Journal of Economic Studies 42(5):861877.

Sepehri, A., and A. H. Akram-lodhi. 2005. Transition, Savings and Growth in Vietnam: a Three-Gap Analysis. Journal of International Development 17(4):553-574.

Siregar, R. 1997. Management of Macroeconomic Policies Vietnam. Rising to the Challenge in Asia: A Study of Financial Markets. Asian Development Bank.

Sjöholm, F. 2006. State Owned Enterprises and Equitization in Vietnam. Stockholm School of Economics, WP-228.

Skully, M., and S. Perera. 2012. Bank Market Power and Revenue Diversification: Evidence from Selected ASEAN Countries. Journal of Asian Economics 23(6):688-700. 
Soedarmono, W., F. Machrouh, and A. Tarazi. 2011. Bank Market Power, Economic Growth and Financial Stability: Evidence from Asian Banks. Journal of Asian Economics 22(6):460-470.

Stiglitz, J.E. 2016. Rewriting the Rules of the American Economy. New York, NY: W.W. Norton.

Thanh, V. T., T.T. Cuong, B. Dung, and T.D. Chieu. 2011. Small and Medium Enterprises Access to Finance in Vietnam. In Small and Medium Enterprises Access to Finance in Selected East Asian Economies (pp.151-192), edited by C. Harvey, S. Oum, and D.A. Narjoko. Jakarta: Economic Research Institute for ASEAN and East Asia.

Pham, T.T.T., and J. Riedel. 2012. On the Conduct of Monetary Policy in Vietnam. Asian-Pacific Economic Literature 26(1):34-45.

Volz, U. 2013. ASEAN Financial Integration in the Light of Recent European Experiences. Journal of Southeast Asian Economies 30(2):124-141.

Vuong, Q.H. 2010. Financial Markets in Vietnam's Transition Economy: Facts, Insights, Implications. Saarbrücken, Germany: VDM Verlag.

Vuong, Q.H. 2016(a). Determinants of Firm Performance in a Less Innovative Transition System: Exploring Vietnamese Longitudinal Data. International Journal of Transitions and Innovation Systems 5(1): 20-45.

Vuong, Q.H. 2016(b). Impacts of Geographical Locations and Sociocultural Traits on the Vietnamese Entrepreneurship. SpringerPlus 5(1): 1189. DOI: 10.1186/s40064-0162850-9.

Vuong, Q.H. (2019). The financial economy of Viet Nam in an age of reform, 1986-2016. In U. Volz, P. Morgan and N. Yoshino (Eds.) Routledge Handbook of Banking and Finance in Asia (pp. 201-222). New York, NY: Routledge.

Vuong, Q.H., and N.K. Napier. 2014. Resource Curse or Destructive Creation in Transition: Evidence from Vietnam's Corporate Sector. Management Research Review 37(7):642-657.

Vuong, Q. H., and N.K. Napier. 2015. Acculturation and Global Mindsponge: An Emerging Market Perspective. International Journal of Intercultural Relations 49:354-367.

Vuong, Q.H., N.K. Napier, and D.E. Samson. 2014. Relationship between Innovations, Capital Expenditures and Post-M\&A Performance: Evidence from Vietnam, 2005-2012. IUP Journal of Business Strategy 11(1):1-8.

Vuong, Q.H., N.K. Napier, and T.D. Tran. 2013. A categorical data analysis on relationships between culture, creativity and business stage: the case of Vietnam. International Journal of Transitions and Innovation Systems 3(1): 4-24.

Vuong, Q.H., Q.H. Vu, and T.T. Vuong. 2016. Relationship between Past Experience, Social Network Participation and Creative Capacity: Vietnamese Entrepreneurship in Transition. International Journal of Transitions and Innovation Systems 5(3/4):299313.

Wang, K.M., and H. C. Lai. 2013. Which Global Stock Indices Trigger Stronger Contagion Risk in the Vietnamese Stock Market? Evidence using a Bivariate Analysis. Panoeconomicus 60(4):473-497.

Wood, A. 1989. Deceleration of Inflation with Acceleration of Price Reform: Vietnam's Remarkable Recent Experience. Cambridge Journal of Economics 13(4):563-571.

WB. 2014. Vietnam's Financial Sector Assessment. WB/FSAP. Washington, DC: World Bank. Yoshino, N. and F. Taghizadeh-Hesary. 2014. Analytical Framework on Credit Risks for Financing Small and Medium-sized Enterprises in Asia. Asia-Pacific Development Journal 21(2):1-21.

Yu, S. Q. 2008. Vietnam: Quo-Vadis? Asia Competitiveness Institute. 